\title{
Thematic and Methodological Trends of Computational Thinking Skills-Related Graduate Theses in Turkey
}

\author{
Mithat ELÇİÇEK*
}

\begin{abstract}
The purpose of this research is to analyse the thematic and methodological trends of computational thinking skills-related graduate theses in Turkey. Within the scope of this purpose, a total of 38 works, including 30 Master's and 8 doctoral studies, published in the National Thesis Centre database of YÖK (Council of Higher Education), were analysed using a document analysis model, one of the qualitative research methods. A descriptive content analysis technique was used to examine graduate theses. According to the results of the research, it has been concluded that the effects of programming teaching, robotics, and block-based visual programming on computational thinking skills are examined in graduate theses. It has been determined that a very limited number of design and development studies have been carried out to develop computational thinking skills. It has been observed that the majority of graduate theses were made in the field of Computer Education and Instructional Technology and most theses were published in 2019. It has been concluded that graduate theses are mostly designed by using the quantitative research method and quasi-experimental design, and secondary school sample profile is mostly preferred in the studies. However, it has been seen that the data collected by using a scale, interview, and observation data collection tools are analysed in accordance with predictive analysis techniques. As a result of the research, it has been recommended that design studies should be carried out in which qualitative or mixed research methods are used and especially pre-school sample profiles are preferred.
\end{abstract}

Keywords: Computational thinking, graduate theses, content analysis.

\footnotetext{
* Orcid ID: https://orcid.org/0000-0003-1845-7271, Dr., Siirt Üniversitesi, Türkiye,
} mithatelcicek@gmail.com 


\section{INTRODUCTION}

In today's world that evolves from the industrial society to the information society, a global race has begun with intense competition based on technology production. The ability of societies to come out of this global race with an effective struggle is directly related to the information and communication competencies of individuals who make up the society (Tosik-Gün \& Güyer, 2019). For, societies consisting of individuals who only consume technology cannot be expected to take an active part in this race. Therefore, societies have made reforms in many areas, especially in educational policies, for the human profile they need (Israel, Pearson, Tapia, Wherfel, \& Reese, 2015; Mannila et al., 2014; Wong et al., 2015). The reforms aim to raise individuals equipped with effective problem-solving skills and capable of designing complex systems (Tosik-Gün \& Güyer, 2019). In this context, some competencies defined as 21 st-century skills provide a dynamic framework for the human profile that societies need (Üzümcü \& Bay, 2018). Computational thinking skills have recently been added to this framework, which includes competencies such as collaboration, problem-solving, critical thinking, analytical thinking, and design thinking (International Society for Technology in Education, 2015). There are many definitions made in different contexts for computational thinking, whose popularization process started with the study of Janette Wing in 2006 (Gonzalez, 2015; Grover \& Pea, 2013; Kalelioğlu, Gülbahar, \& Kukul, 2016, Wing, 2008). One of these definitions was made by ISTE (International Society for Technology in Education) and CSTA (Computer Science Teachers Association). As is specified within this definition, computational thinking is explained as the problem-solving process in which editing, analysis, formulation, automatization, transfer, and generalization processes are performed by means of computers (ISTE \& CSTA, 2011). Another definition was made by the Carnegie Mellon University Computing Thinking Centre. According to the definition, computational thinking is the process of understanding the problem using the basic concepts of computer science, developing effective solutions to the problem, and the application and generalization of the solution through the system design approach (Centre for Computational Thinking Carnegie Mellon, 2019). Riley and Hunt (2014) express computational thinking as a problem-solving process based on algorithmic thinking by emphasizing cognitive processes. Although the definitions differ, it is understood that the focal point is structured on the axis of problem-solving.

Problem-solving is an important skill not only for a certain discipline or professional group, but also for individuals from all walks of life (Care, Scoular, \& Griffin, 2016; Griffin, 2017). Especially the fact that the problem situations encountered in daily life have turned into a more complex structure compared to the past has increased the need for new solution strategies (Griffin, 2017). One of these new solution strategies is the work done to develop computational thinking skills (ISTE, 2015). Computational thinking skills are aimed at increasing the life success of the individual, preparing them better for business and education life, and ensuring that they can compete on a global scale (Lee et al., 2011; Snalune, 2015; Wing, 2008). For this purpose, activities and applications, in which content such as programming, robotics, computer games, simulation, and coding are used 
extensively to improve computational thinking skills, have been developed (Bers, 2010; Magana \& Silva Coutinho, 2017; Oluk, Korkmaz \& Oluk, 2011).

The development of computational thinking skills has recently become the focus of the attention of researchers and policymakers in Turkey, as in all countries (Gulbahar and Kalelioğlu, 2018; Tang Chou and Tsai, 2020). In this context, new course contents are prepared for the development of computational thinking skills, and the teaching programs are renewed. For example, America, Estonia, South Korea, and some European Union countries have updated their curricula and added new contents such as programming and coding (Demirer \& Sak, 2016; Gülbahar \& Kalelioğlu, 2018). The "Information Technologies" course curriculum has been enriched with software and coding contents by the Board of Education and Discipline in Turkey.

Similarly, new activities continue to be prepared for different disciplines (Kaan, Çalışkan, \& Yetişir, 2017). In addition, it is known that there has been a significant increase in articles, master's theses, and doctoral dissertations on computational thinking skills (İliç, Haseski, \& Tuğtekin, 2018; Kalelioğlu, 2018). In the study conducted by Tang, Chou, and Tsai (2020), considering the studies on computational thinking skills between 2006 and 2018, it was observed that the number of studies on computational thinking skills increased significantly after 2013. Similarly, in the content analysis study conducted by Haseski, Ilic, and Tugtekin (2018) using Web of Science and ERIC databases, it was found that the number of publications for computational thinking skills increased more than twice after 2010. Referring to the results of research conducted worldwide, it is seen that Turkey ranks in the top ten with the number of publications between 2020 and 2010 (Tang Chou and Tsai, 2020).

Researches show a remarkable increase in the number of studies in recent years regarding computational thinking skills in Turkey (Ilic, Haseski and Tuğtekin, 2018; Kalelioğlu, 2018). In this context, there is a need for studies that will provide a general framework in determining the tendencies, gaps, and clutter for studies on computational thinking skills. Turkey has seen a limited number of research studies on computational thinking skills, (Haseski, Ilic and Tuğtekin, 2018; Kalelioğlu, 2018; Kalelioğlu, Gulbahar and Kukul, 2016; Tosik-Gün and Güyer, 2019). However, there is no study that investigates graduate theses on computational thinking skills. Considering the number of graduate theses on computational thinking skills in Turkey, it is thought that there is a need for content analysis studies that will investigate trends, gaps, or clutters regarding these with a holistic perspective. Providing a general framework for the theses on computational thinking skills conducted following an analysis of relevant these in Turkey is important in terms of being a guide for researchers to work in related fields. The aim of the research in this context is to examine the thematic and methodological trends of computational thinking skills-related graduate theses in Turkey. While the purpose and problem statements of the theses, their distribution according to disciplines, and the years of publication were examined thematically, research methods, patterns, profiles of sample, data collection tools, and data analysis techniques of graduate theses were examined methodologically. In this way, the research aims to present a general 
framework by revealing the similarities and differences of the studies and to guide researchers who will work in this field. In this context, potential answers were sought for the following research questions.

1. What are the general characteristics of computational thinking skills-related graduate thesis made in Turkey thematically?

a. Which topics have been studied in graduate theses?

b. How are they distributed according to the branches of science?

c. What is the distribution according to the years of publication?

2. What are the general characteristics of computational thinking skills-related graduate thesis made in Turkey methodologically?

a. Which research methods have been used in graduate theses?

b. Which research model or patterns have been chosen?

c. What are the sample profiles?

d. What data collection tools have been used?

e. What are the techniques of data analysis used in graduate theses?

\section{METHOD}

This study was designed using the document analysis model, one of the qualitative research methods, based on the process followed. Document analysis is a frequently used research method for systematically analysing written sources planned to be researched (Karasar, 2016). Within the scope of the study, graduate theses on computational thinking skills published until April 2020 were examined thematically and methodologically. The main purpose of the analysis of the related graduate theses is to reveal the trends, gaps or clutter in the field of computational thinking skills. For this purpose, the descriptive content analysis design was used in the study. Descriptive content analysis is a method used to obtain summary information or present a general view about previously published works, depending on a predetermined framework (Büyüköztürk et al., 2008; Çalık \& Sözbilir, 2014). The descriptive content analysis consists of steps that include data collection and data analysis. In this context, firstly, data were collected through database scanning in the current study, and then these data were analysed and interpreted according to research questions.

\section{Data Collection}

The sample of the study consists of graduate theses on computational thinking skills found in the database of YÖK (Higher Education Council) National Thesis Centre and published until April 2020. For this reason, instead of limiting any date range, all graduate theses published until April 2020 were included in the study. The keywords used in the database search consist of the words used for the concept of computational thinking in line with the relevant literature. Computational thinking was seen to be used in different words in Turkish as "kompütasyonel” by (Şahiner \& Kert, 2016), "bilgisayarca” by (Korkmaz, Çakır, 
\& Özden, 2015), “bilişimsel” by (Özkeş, 2016), "bilgisayımsal” by (Çınar \& Tüzün, 2017), and "hesaplamalı" by (Özçınar, 2017). In this context, queries were made for each of these keywords in the database of the national thesis centre without date and field restrictions, and related works were reached. In the queries, a total of 63 results were obtained: 43 for computational thinking, 0 for kompütasyonel, 14 for bilgisayarca, 3 for bilişimsel, 0 for bilgisayımsal, and 3 for hesaplamalı. In the preliminary examination, after 13 studies that were unrelated to computational thinking skills, 2 non-accessible and 10 repetitive studies were excluded, a total of 38 graduate theses, including 30 master's and 8 doctoral theses, were examined within the scope of the research (See Appendix-1). In the examination of the theses, the form prepared by the researcher was used based on similar studies previously conducted. This form consists of two parts, thematic and methodological. The thematic part keeps track of information on the subject studied in the thesis, the discipline in which the thesis was prepared, and the year the thesis was published, while the methodological part keeps track of the method, design, sample, data collection tools used, and the analysis method of the research.

\section{Data Analysis}

During the data analysis process, the stages of document review followed by Şimşek and Yaşar (2019) in their studies were followed. In the first stage, the theses were saved in two folders as Master's degrees and doctorate degrees. Starting from the master's theses, each one was given a code according to the thesis number order given by the National Thesis Centre. These codes were used in the analysis and presentation of the findings. In the second stage, the data obtained for each research problem were entered in an Excel sheet with the code of the thesis. In the third stage, the tables were prepared by examining the data on the Excel sheet in detail. In the fourth and last stage, the data were presented in the tables with their frequencies within the framework of research questions.

In order to ensure the reliability of the data analysis, the stage during which the data were entered into Excel and coded was carried out by an expert together with the author. Reliability coefficient $=$ [Agreement $/$ (Agreement + Disagreement $)] \mathrm{x} 100$ formula suggested by Miles and Huberman (1994) was used for the percentage of agreement between coders. The reliability coefficient was calculated as 0.84 . In codings where an agreement could not be reached, the agreement was achieved by bringing the coders together. In order to ensure the validity of the research, the theses were examined in detail and in-depth by both coders during the data analysis process. The obtained data were presented in tables with their codes.

\section{FINDINGS}

The findings obtained within the scope of the research are presented in two sections. In the first section, the thematic general features of the graduate theses on computational thinking skills were examined, and in the second section, the methodological general features were examined. 
The Thematic General Features Of The Graduate Theses In Turkey Made Related To Computational Thinking Skills

In this section, information about the topics covered in the graduate theses, their distribution according to the branches of science, and the publication years and types of the graduate theses are presented. Information on the topics covered in graduate theses is given in Table 1 .

Table 1.

Topics Covered in Graduate Theses

\begin{tabular}{|c|c|c|c|c|}
\hline Topics & & Master's & Doctorate & $\mathrm{f}$ \\
\hline \multirow{10}{*}{$\begin{array}{l}\text { The analysis of } \\
\text { the effects of } \\
\text { various } \\
\text { variables on } \\
\text { the CT skill }\end{array}$} & $\begin{array}{l}\text { - Project-based learning } \\
\text { method }\end{array}$ & M15, M13* & & 2 \\
\hline & $\begin{array}{l}\text { - Flipped classroom } \\
\text { application }\end{array}$ & M1, M3 & & 2 \\
\hline & $\begin{array}{l}\text { - Technology-supported } \\
\text { schematic organisers }\end{array}$ & & D8* & 1 \\
\hline & $\begin{array}{l}\text { - Problem-based learning } \\
\text { method }\end{array}$ & M9 & & 1 \\
\hline & $\begin{array}{l}\text { - Reflective thinking } \\
\text { activities }\end{array}$ & M11, M27 & & 2 \\
\hline & - Educational games & M6 & & 1 \\
\hline & $\begin{array}{l}\text { - Gamification of the } \\
\text { learning process }\end{array}$ & M25 & & 1 \\
\hline & $\begin{array}{l}\text { - Computer-aided math } \\
\text { activities }\end{array}$ & & D1 & 1 \\
\hline & $\begin{array}{l}\text { - Schematic organisers } \\
\text { such as fishbone, } \\
\text { brainstorm and } \\
\text { flowchart }\end{array}$ & & D8 & 1 \\
\hline & $\begin{array}{l}\text { - Information } \\
\text { Technologies and } \\
\text { Software course } \\
\text { activities }\end{array}$ & M14, M17, M19* & & 3 \\
\hline
\end{tabular}




\begin{tabular}{|c|c|c|c|c|}
\hline & - $\quad$ Programming teaching & $\begin{array}{l}\text { M3, M5*, M9, } \\
\text { M16*, M23* }\end{array}$ & D3, D5* & 7 \\
\hline & $\begin{array}{l}\text { - Programming without a } \\
\text { computer }\end{array}$ & M16, M23, M19 & & 3 \\
\hline & 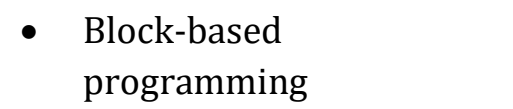 & M12, M29, M30 & D6 & 4 \\
\hline & $\begin{array}{l}\text { Robot-assisted } \\
\text { programming }\end{array}$ & M5 & & 1 \\
\hline & $\begin{array}{l}\text { - The use of an educational } \\
\text { robotic set }\end{array}$ & $\begin{array}{l}\text { M4, M13, M26, } \\
\text { M28 }\end{array}$ & & 4 \\
\hline & - $\quad$ STEM-based activities & M10 & & 1 \\
\hline $\begin{array}{l}\text { The analysis of } \\
\text { the relationship }\end{array}$ & $\begin{array}{l}\text { - Creative problem-solving } \\
\text { skills }\end{array}$ & M18 & & 1 \\
\hline $\begin{array}{l}\text { between } \\
\text { various } \\
\text { variables and }\end{array}$ & $\begin{array}{l}\text { - Logical-mathematical } \\
\text { intelligence apperception }\end{array}$ & $\mathrm{M}^{*}$ & & 1 \\
\hline the CT skill & - Academic success & M2, M22 & & 2 \\
\hline & - Readiness to learn online & M7 & & 1 \\
\hline $\begin{array}{l}\text { Design and } \\
\text { development }\end{array}$ & $\begin{array}{l}\text { Data visualization } \\
\text { application }\end{array}$ & M20 & & 1 \\
\hline $\begin{array}{l}\text { studies to } \\
\text { improve the CT }\end{array}$ & - Learning environment & M8 & & 1 \\
\hline skill & - Instructional design & M24 & D7 & 2 \\
\hline & - Program design & & D4 & 1 \\
\hline & - Activity & & D2, D5 & 2 \\
\hline $\begin{array}{l}\text { Performance-bas } \\
\text { using machine le }\end{array}$ & $\begin{array}{l}\text { ed evaluation of the CT skill } \\
\text { arning }\end{array}$ & M21 & & 1 \\
\hline Total & & & & 48 \\
\hline
\end{tabular}

* Studies involving more than one theme.

While determining the themes of the graduate theses, the themes were determined according to the focus points of the studies by examining the purpose of the studies and the problem sentences. In this context, Table 1 reveals that most studies are in the study themes (f: 35) where the effects of various variables on the CT skill are examined. These studies are followed by design and development studies (f: 7) for the development of the 
CT skill, and studies (f: 5) that examine the relationship between various variables and the CT skill. However, one may notice that the least amount of work was done in the performance-based evaluation (f: 1 ) theme of the CT skill using machine learning.

It is seen in studies examining the effects of various variables on the CT skill that the themes of programming teaching (f: 7), the use of the educational robotic set (f: 4) and block-based programming (f: 4) were mostly discussed. In studies examining the relationship between various variables and the CT skill, the theme of academic achievement (f: 2) was the most discussed. In the design and development studies for the development of the CT skill, there were studies where the most activity (f: 2 ) design was carried out. A distribution of graduate theses according to disciplines is given in Table 2 .

Table 2

Distribution of graduate theses according to disciplines

\begin{tabular}{|c|c|c|c|}
\hline Disciplines & Master's & Doctorate & $\mathrm{f}$ \\
\hline $\begin{array}{ll} & \text { Computer } \\
\text { engineering }\end{array}$ & M21 & & 1 \\
\hline $\begin{array}{l}\text { - Computer and } \\
\text { instructional } \\
\text { technology } \\
\text { education }\end{array}$ & $\begin{array}{l}\text { M1, M3, M4, M5, M6, M9, M11, M13, } \\
\text { M14, M15, M16, M17, M20, M22, M23, } \\
\text { M24, M25, M27, M28, M29, M30 }\end{array}$ & D1, D2, D3, D8 & 25 \\
\hline $\begin{array}{l}\text { - Educational } \\
\text { Sciences }\end{array}$ & M7, M18 & D4, D6, D7 & 5 \\
\hline $\begin{array}{ll}\text { - } & \text { Education } \\
\text { technologies }\end{array}$ & M12, M19 & & 2 \\
\hline - Informatics & M26 & D5 & 2 \\
\hline - Science education & M1, M10 & & 2 \\
\hline $\begin{array}{l}\text { - Internet and } \\
\text { information } \\
\text { technology } \\
\text { management }\end{array}$ & M8 & & 1 \\
\hline Total & & & 38 \\
\hline
\end{tabular}

As can be seen in Table 2, graduate theses on computational thinking skill are mostly made in the field of Computer and Instructional Technology (f: 25) followed by Educational Sciences (f: 5), Educational Technologies (f: 2), Informatics (f: 2), Science (f: 
2), Computer Engineering (f: 1), Internet and Information Technology Management (f: 1). A distribution of graduate theses according to the years of publication is given in Table 3.

Table 3

A distribution of graduate theses according to the years of publication

\begin{tabular}{rrllc}
\hline Years & \multicolumn{1}{l}{ Master's } & Doctorate & $\mathrm{f}$ \\
\hline$\bullet$ & 2016 & & D8 & 1 \\
$\bullet$ & 2017 & M1, M2, M30 & & 3 \\
$\bullet$ & 2018 & M3, M4, M5, M6, M7 & D1, D2, D3 & 8 \\
$\bullet$ & 2019 & M8, M9, M10, M11, M12, M13, M14, M15, M16, & D4, D5, D7 & 25 \\
& & M17, M18, M19, M20, M21, M22, M23, M24, M25, & & \\
& & M26, M27, M28, M29 & & \\
\hline Total & 2020 & & D6 & 38 \\
\hline
\end{tabular}

Considering the distribution of the graduate theses on computational thinking skills in Table 3, it is seen that the first study was published in 2016 and most studies were published in 2019 (f: 25). However, the data used in this study are limited to graduate theses published until April 2020. Therefore, there may be an increase in the number of graduate theses published in 2020 in the future. Considering this exceptional situation, it is seen that there has been an increase in the number of graduate theses on computational thinking skills over the years (2016-2019).

\section{The methodological general features of the graduate theses in Turkey made related to computational thinking skills}

In this section, information about research methods, research models, sample profiles, data collection tools, and data analysis techniques used in graduate theses is presented. Information on research methods used in graduate theses is given in Table 4 . 
Table 4

Research Methods Used in Graduate Theses

\begin{tabular}{cllll}
\hline \multicolumn{1}{l}{ Method } & Master's & Doctorate & $\mathrm{f}$ \\
\hline$\bullet$ & The & M1, M2, M5, M6, M7, M9, M10, M12, & \\
\\
quantitative & M13, Y14, Y15, Y16, Y17, Y18, Y19, & \\
& Y21, Y22, Y23, Y26, Y28 & & \\
$\bullet$ & Qualitative & Y8, Y11, Y24, Y27, Y29 & D2, D8 & 7 \\
$\bullet \quad$ Mixed & Y3, Y4, Y20, Y25, Y30 & D1, D3, D4, D5, D6, & 11 \\
& & D7 & 38 \\
\hline Total & & & \\
\hline
\end{tabular}

Table 4 reveals that although the the quantitative research method (f: 20 ) is mainly used in graduate theses, there is no doctoral thesis published using only the the quantitative method. It is seen that the mixed research method (f: 6) is used in most of the doctoral dissertations. However, the qualitative research method was used least in graduate theses. Research designs/models used in graduate tests are given in Table 5.

Table 5

Research Patterns/Models Used in Graduate Theses

\begin{tabular}{|c|c|c|c|}
\hline Design/Model & Master's & Doctorate & $\mathrm{f}$ \\
\hline $\begin{array}{l}\text { - Descriptive sequential } \\
\text { pattern }\end{array}$ & M3 & & 1 \\
\hline - $\quad$ Case studM & M11, M24, M25, M27, M29 & D8 & 6 \\
\hline - Descriptive survey & M2, M7, M22 & & 3 \\
\hline - Relational survey & M18 & & 1 \\
\hline - Experimental & M10, M12, M28 & & 3 \\
\hline - Development research & & D2 & 1 \\
\hline $\begin{array}{l}\text { - Embedded experimental } \\
\text { design }\end{array}$ & M4 & D7 & 2 \\
\hline $\begin{array}{l}\text { - Exploratory sequential } \\
\text { design }\end{array}$ & & D6 & 1 \\
\hline
\end{tabular}




\begin{tabular}{|c|c|c|c|}
\hline $\begin{array}{l}\text { - Quasi-experimental } \\
\text { design }\end{array}$ & $\begin{array}{l}\text { M1, M5, M6, M9, M13, } \\
\text { M14, M15, M16, M17, } \\
\text { M19, M23, M26, M30 }\end{array}$ & D1, D5 & 15 \\
\hline - Design-based research & M20 & D4 & 2 \\
\hline $\begin{array}{l}\text { - Design and development } \\
\text { research }\end{array}$ & M8 & & 1 \\
\hline $\begin{array}{l}\text { - Convergent parallel } \\
\text { design }\end{array}$ & & D3 & 1 \\
\hline - Unspecified & M21 & & 1 \\
\hline Total & & & 38 \\
\hline
\end{tabular}

As seen in Table 5, the most used research design in graduate theses is the quasiexperimental design (f: 15) followed by case study (f: 6), descriptive survey (f: 3 ) and experimental research model (f: 3). The least used research model/design is descriptive sequential design (f: 1 ), relational survey (f: 1), development research (f: 1 ), exploratory sequential design (f: 1), design and development research (f: 1). ), and convergent parallel pattern (f: 1). In addition, the design was not specified in a study. The sample profile of graduate theses is given in Table 6.

Table 6

Sample Profile of Graduate Theses

\begin{tabular}{|c|c|c|c|}
\hline Sample Profile & Master's & Doctorate & $\mathrm{f}$ \\
\hline - $\quad$ Preschool & & D8 & 1 \\
\hline $\begin{array}{l}\text { - Elementary } \\
\text { School }\end{array}$ & M2*, M8 & & 2 \\
\hline $\begin{array}{l}\text { - Secondary } \\
\text { School }\end{array}$ & $\begin{array}{l}\text { M1, M2, M4, M5, M9, M10, M11, M12, M13, } \\
\text { M14, M16, M18, M19, M22, M23, M25, M26, } \\
\text { M27, M28, M30 }\end{array}$ & $\begin{array}{l}\text { D1, D2*, D3, } \\
\text { D5, D6, D7 }\end{array}$ & 26 \\
\hline - High School & M2, M15, M17*, M20* & & 4 \\
\hline - University & M6, M7 & D4 & 3 \\
\hline - Teacher & M17, M20, M24, M29 & & 4 \\
\hline - Academician & & D2 & 1 \\
\hline Total & & & 41 \\
\hline
\end{tabular}

*Studies with more than one participant profile. 
Table 6 demonstrates that in graduate theses, studies are mainly conducted with secondary school (f: 26) sample profile. This is followed by high school (f: 4), teacher (f: 4) and university (f: 3 ) participant profiles. The least studied sample profile consists of preschool (f: 1) and academician (f: 1) profiles. In addition, since data sets were used as the sample profile in the Y21 coded study conducted in the field of Computer Engineering, they were not included in the table. Data collection tools that were used in graduate theses are given in Table 7.

Table 7

Data Collection Tools Used in Graduate Theses

\begin{tabular}{|c|c|c|c|}
\hline Data Collection Tool & Master's & Doctorate & $\mathrm{f}$ \\
\hline - Questionnaire & M29 & D2* & 2 \\
\hline - Scale & $\begin{array}{l}\text { M1, M2, M3*, M4*, M5, M6, M7, } \\
\text { M9, M10, M12, M13, M14, M15, } \\
\text { M16, M17,M18, M19, M22, M23, } \\
\text { M25*, M26, M28, M30* }\end{array}$ & $\begin{array}{l}\mathrm{D} 1^{*}, \mathrm{D} 3^{*}, \mathrm{D} 5^{*}, \mathrm{D} 6 * \\
\mathrm{D} 7^{*}\end{array}$ & 28 \\
\hline - Rubric & M20* & D2, D4, D7 & 4 \\
\hline - Inventory & M30 & & 1 \\
\hline - Graded scoring key & & D6 & 1 \\
\hline - Evaluation form & & D8 & 1 \\
\hline - Observation & $\mathrm{M} 24^{*}, \mathrm{M} 27^{*}$ & D3, D6, D7 & 5 \\
\hline - Daily & M11*, M27 & D4 & 3 \\
\hline - Clinical interview & & D2 & 1 \\
\hline - Engagement & M11, M27 & D1 & 3 \\
\hline - Interview & $\begin{array}{l}\text { M3, M4, M8, M20, M24, M25, } \\
\text { M29, M30 }\end{array}$ & $\begin{array}{l}\text { D2, D4, D5, D6, } \\
\text { D7, D8 }\end{array}$ & 14 \\
\hline
\end{tabular}

Total 63

* Studies using more than one data collection tool.

As seen in Table 7, the most used data collection tools in graduate theses are scale (f: 28), interview (f: 14), observation (f: 5) and rubric (f: 4), respectively. The least used data collection tools are inventory (f: 1), graded scoring key (f: 1), evaluation form (f: 1), and clinical interview (f: 1). Also, since the data collection tool used in the study coded Y21was 
not specified, it was not included in the table. Data analysis techniques used in graduate theses are given in Table 8.

Table 8

Data Analysis Techniques Used in Graduate Theses

\begin{tabular}{|c|c|c|c|c|}
\hline \multicolumn{2}{|c|}{ Data analysis technique } & \multirow{2}{*}{$\begin{array}{l}\text { Master's } \\
\text { M2, M4, M18*, M20*, M23*, } \\
\text { M25*, M28*, M29*, M30* }\end{array}$} & \multirow{2}{*}{$\begin{array}{l}\text { Doctorate } \\
\mathrm{D}^{*}, \quad \mathrm{D} 3^{*}, \quad \mathrm{D} 4^{*}, \\
\mathrm{D}^{*}, \mathrm{D} 7^{*}, \mathrm{D} 8^{*}\end{array}$} & \multirow{2}{*}{$\begin{array}{l}\mathrm{f} \\
15\end{array}$} \\
\hline Descriptive & $\begin{array}{l}\text { - Frequency, } \\
\text { percentage, } \\
\text { mean, standard } \\
\text { deviation, etc. }\end{array}$ & & & \\
\hline \multirow[t]{9}{*}{ Predictive } & - $\quad$ T-Test & $\begin{array}{l}\text { M1, M3, M7*, M9, M10, } \\
\text { M14, M16*, M17*, M18, } \\
\text { M25, M28, M30 }\end{array}$ & D5*, D7 & 14 \\
\hline & - Ancova & & D3, D6 & 2 \\
\hline & - Anova & M7*, M9, M16," M18, M19 & D3, D7 & 7 \\
\hline & - Mancova & & D6 & 1 \\
\hline & - Manova & M5 & & 1 \\
\hline & $\begin{array}{l}\text { - Mann- Withney } \\
\mathrm{U}\end{array}$ & M13*, M16, & D1*, D5 & 4 \\
\hline & $\begin{array}{l}\text { - Kruskal-Wallis } \\
\mathrm{H}\end{array}$ & M16, M23 & & 2 \\
\hline & - Wilcoxon & $\begin{array}{l}\text { M6, M12, M13, M15, M23, } \\
\text { M26 }\end{array}$ & D1, D5 & 8 \\
\hline & - Correlation & M7, M18, M22 & D8 & 4 \\
\hline Qualitative & $\begin{array}{l}\text { - Content } \\
\text { analysis }\end{array}$ & $\begin{array}{l}\text { M3, M8, M11, M20, M24, } \\
\text { M27, M29, M30 }\end{array}$ & $\begin{array}{l}\text { D1, D2, D4, D5, } \\
\text { D6, D7, D8 }\end{array}$ & 15 \\
\hline
\end{tabular}

Total

* Studies using more than one analysis technique.

Table 8 demonstrates that the most used data analysis techniques in graduate theses are predictive (f: 43 ), descriptive (f: 15 , and content analysis (f: 15 ), respectively. The t-test (f: 14) was the most used technique among predictive analysis techniques, while the least used ones were Mancova (f: 1), Manova (f: 1), Ancova (f: 2), and Kruskal-Wallis H (f: 2) tests. 


\section{CONCLUSION, DISCUSSIONS AND RECOMMENDATIONS}

This study has been designed to examine graduate theses made in Turkey regarding computational thinking graduate thesis. In this context, 38 graduate theses registered in the database of YÖK National Thesis Centre were analysed. According to the results of the analysis, some studies mostly examine the effects of programming teaching, the use of educational robotic set, and block-based visual programming on computational thinking skills in graduate theses. This result is in line with the result of the research conducted by Kalelioglu (2018), revealing that there is increased importance given to programming teaching and that the research on the effects of programming teaching on computational thinking skill is a crucial subject matter for researchers. As a matter of fact, the literature review shows that it is possible to reach a great number of studies on the effects of programming teaching on computational thinking (Atmatzidou \& Demetriadis, 2018; Djambong \& Freiman, 2016; Nouri, Zhang, Mannila, \& Noren, 2019; Pérez-Marín, HijónNeira, Bacelo and Pizarro, 2020; Portelance and Bers, 2015).

Another result is that the number of theses for the development of computational thinking skills that focus on activity, learning environment or program design is quite low although it is known that activity, learning environment or program design play crucial roles in the process of developing computational thinking skills (Wing, 2008). Therefore, the low number of design studies aimed at developing computational thinking skills indicates a gap in the field, which means that this gap may have been ignored by the researchers working on a thesis on computational thinking skill.

Considering the distribution of theses on computational thinking skills, one may notice that the majority of them are made in the field of Computer Education and Instructional Technology. This may be because the concept of computational thinking skill is expressed in its simplest form as "problem-solving by using technology" (Gretter \& Yadav, 2016) and mainly computer science and programming contents are used in studies on computational thinking skills (Bers, Flannery, Kazakoff, \& Sullivan, 2014); Caldwell \& Smith, 2016). It is observed that very few studies have been conducted in the fields of Educational Sciences, Educational Technologies, Informatics, Science Education, Internet and Information Technology Management and Computer Engineering. It is thought that more research on these disciplines of science is likely to make important contributions to the development of computational thinking skills.

The number of graduate theses on computational thinking skills is quite limited. What is clear is that graduate theses have started to emerge since 2016, while most of the theses were published in 2019. Computational thinking skill is a relatively new field of study, thus considering that a graduate thesis can be published following a study of two years, the first studies actually started before 2016. However, the data used in this study are limited to graduate theses published until April 2020. Therefore, there may be an increase in the number of graduate theses published in the future. Considering this exception, it is possible to maintain that there has been an increase in the number of graduate theses on computational thinking skill over the years (2016-2019). This result coincides with the 
results of the research conducted by Haseski, Ilic and Tugtekin, (2018), Tang, Chou, and Tsai (2020). Similarly, when the studies conducted by Tang et al. (2020) on computational thinking skill between 2006 and 2018 were examined, it was concluded that there was a great increase in the number of studies on computational thinking between 2013 and 2018.

When the graduate theses were analysed methodologically, it was concluded that the majority of the studies were designed using the quantitative research method and quasiexperimental design. This situation is thought to be related to the subject, purpose, and data collection tools used in theses. In this context, it can be said that the quantitative research method may have been preferred more since most of the graduate theses aim to determine the effects of different variables on computational thinking skills. It is thought that the quantitative method and quasi-experimental design may have been preferred more, as the the use of scale as a data collection tool in graduate theses is mostly preferred. In other words, it can be said that the research method may change according to the purpose of the research. In addition, it is thought that the preference of the quantitative research methods in graduate theses may be due to the fact that the theses selected for the research are mainly master theses. Shorter data collection and application processes in the quantitative research methods compared to qualitative research may have played an effective role. This result of the research is supported by the results of the research conducted by Kalelioğlu, Gulbahar and Kukul (2016). Kalelioğlu et al. (2016) examined 125 studies on computational thinking skills. As a result of the analysis of the articles according to their types and research methods, it was determined that the quantitative research methods (f: 33) were used more than other methods (f: 31).

When the theses on computational thinking skills were examined in terms of sample profiles, it was seen that the secondary school level was preferred most in graduate theses. This is followed by high school and university levels, respectively. This result of the research parallels the results of research conducted by De Araujo, Andrade and Guerrero (2016); İlic and Haseski (2019); Tang, Chou, and Tsai (2020). In graduate theses, the fact that computational thinking skill was mostly examined with the student dimension may have been effective in preferring to study with secondary school students in graduate theses. However, it is observed that few studies have been conducted with academicians and preschool sample groups. However, the acquisition of computational

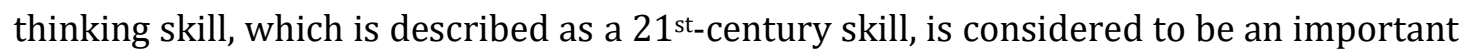
issue that should be emphasized in all age groups and education levels (Wing, 2008).

Scale, interview, and observation data collection tools were mainly used in graduate theses. Similarly, in the studies conducted by De Araujo, Andrade and Guerrero (2016), and Weinberg (2013), it has been determined that data collection tools such as tests, questionnaires, and interviews are mostly used for computational thinking skills. In the analysis of the collected data, it was seen that mostly predictive, descriptive, and content analysis techniques were used respectively. While the t-test was used mostly in predictive analysis, content analysis was used in qualitative analysis. It is thought that the the use of 
quasi-experimental design as one of the the quantitative research designs may have been effective in using t-test mostly in graduate theses.

As a result of the research, studies examining the effect of different variables on computational thinking skill are more frequently observed in graduate theses on computational thinking skills. On the other hand, it is seen that the number of graduate theses, in which learning environment, instructional design, program design or activity designs are made for the development of computational thinking skills, is quite low. In this context, conducting researches in which activities, practices or learning environment designs are made to support computational thinking skills can make significant contributions to the field. It is seen that the quantitative research method is mostly preferred in graduate theses. In this context, it is recommended that research be conducted using qualitative or mixed research methods. In graduate theses, it is seen that there are very few studies conducted with pre-school sample groups. In this context, it is thought that pre-school sample groups will contribute significantly to the literature for graduate theses about computational thinking skills.

\section{References}

Atmatzidou, S., Demetriadis, S., \& Nika, P. (2018). How does the degree of guidance support students' metacognitive and problem-solving skills in educational robotics? Journal of Science Education and Technology, 27(1), 70-85.

Bers, M. U. (2010). The tangiblek robotics program: Applied computational thinking for young children. Early Childhood Research \& Practice, 12(2), 1-20.

Bers, M. U., Flannery, L., Kazakoff, E. R., \& Sullivan, A. (2014). Computational thinking and tinkering: Exploration of an early childhood robotics curriculum. Computers \& Education, 72, 145-157.

Büyüköztürk, Ş., Çakmak, E. K., Akgün, Ö. E., Karadeniz, Ş., \& Demirel, F. (2008). Bilimsel araştırma yöntemleri [Scientific Research Methods]. Pegem Akademi, Ankara.

Caldwell, H., \& Smith, N. (2016). Teaching computing unplugged in primary schools: exploring primary computing through practical activities away from the computer. Sage Publication, London.

Care, E., Scoular, C., \& Griffin, P. (2016). Assessment of collaborative problem-solving in education environments. Applied Measurement in Education, 29(4), 250-264.

Center for Computational Thinking Carnegie Mellon (2020). What is computational thinking? Retrieved from https://www.cs.cmu.edu/ CompThink/

Çalık, M., \& Sözbilir, M. (2014). İçerik analizinin parametreleri [Parameters of content analysis]. Eğitim ve Bilim, 39(174), 33-38.

Çınar, M., \& Tüzün, H. (2017). Eğitimde bilgisayımsal düşünme uygulamalarına ilişkin bir alanyazın incelemesi [A literature review on computational thinking practices in education]. Paper presented at Uluslararası Bilgisayar ve Öğretim Teknolojileri Eğitimi Sempozyumu. Ínöünü University, Malatya, Turkey.

De Araujo, A. L. S. O., Andrade, W. L., \& Guerrero, D. D. S. (2016, October). A systematic mapping study on assessing computational thinking abilities. Proceeding of the IEEE FRONTIERS in 
Education Conference, USA. Retrieved from https://ieeexplore.ieee.org/abstract/document/7757678

Demirer, V., \& Sak, N. (2016). Dünyada ve Türkiye'de programlama eğitimi ve yeni yaklaşımlar [Programming education and new approaches around the world and in Turkey]. Eğitimde Kuram ve Uygulama, 12(3), 521-546.

Djambong, T., \& Freiman, V. (2016, October). Task-based assessment of students' computational thinking skills developed through visual programming or tangible coding environments. Proceeding of the Cognition and Exploratory Learning in the Digital Age Conference, Mannheim, Germany. Retrieved from https://files.eric.ed.gov/fulltext/ED571389.pdf

Gonzalez, M. R. (2015, July). Computational thinking test: Design guidelines and content validation. Proceeding of the 7th International Conference on Education and New Learning Technologies, Barcelona, Spain. Retrieved from https://library.iated.org/view/ROMANGONZALEZ2015COM

Gretter, S., \& Yadav, A. (2016). Computational thinking and media \& information literacy: An integrated approach to teaching twenty-first century skills. TechTrends, 60(5), 510-516.

Griffin, P. (2017). Innovative assessment of collaboration. Springer, Cham

Grover, S., \& Pea , R. (2013). Computational thinking in K-12: A review of the state of the field. Educational Researcher, 42, 38-43.

Gülbahar, Y., \& Kalelioğlu, F. (2018). Bilişim teknolojileri ve bilgisayar bilimi: Öğretim programı güncelleme süreci [Information and communication technologies and computer science: The process of curriculum development]. Millî Eğitim Dergisi, 47(217), 5-23.

Haseski, H. İ., Ilic, U., \& Tugtekin, U. (2018). Defining a new 21st century skill-computational thinking: concepts and trends. International Education Studies, 11(4), 29-42.

Ilic, U., Haseski, H. İ., \& Tugtekin, U. (2018). Publication trends over 10 years of computational thinking research. Contemporary Educational Technology, 9(2), 131-153.

Israel, M., Pearson, J. N., Tapia, T., Wherfel, Q. M., \& Reese, G. (2015). Supporting all learners in school-wide computational thinking: A cross-case qualitative analysis. Computers \& Education, 82, 263-279.

ISTE ve CSTA. (2011). Operational definition of computational thinking for $K-12$ education. Retrieved from https://id.iste.org/docs/ct-documents/computational-thinkingoperational-definition-flyer.pdf?sfvrsn=2

International Society for Technology in Education (2015). Computational thinking for all. Retrieved from https://www.iste.org/explore/Solutions/Computational-thinking-for-all

İlic, U., \& Haseski, H. İ. (2019, Kasım). Bilgi işlemsel düşünmeyi ölçmeye yönelik geliştirilen veri toplama araçlarının incelenmesi [Examination of data collection tools developed to measure computational thinking] [Abstract]. I. Uluslararası Bilim Eğitim Sanat ve Teknoloji, İzmir, Turkey. Retrieved from http://ubest.deu.edu.tr/BEST2018/tam-metin-bildiri-kitabi

Kaan, B. A. T. I., Çalışkan, İ., \& Yetişir, M. İ. (2017). Fen eğitiminde bilgi işlemsel düşünme ve bütünleştirilmiş alanlar yaklaşımı (STEAM) [Computational thinking and integrative education (STEAM) in science education]. Pamukkale Üniversitesi Eğitim Fakültesi Dergisi, 41(41), 91-103. 
Kalelioğlu F. (2018). Characteristics of studies conducted on computational thinking: a content analysis. In: Khine M. (eds) Computational thinking in the stem disciplines, 11-99. Springer, Cham

Kalelioğlu, F., Gülbahar, Y., \& Kukul, V. (2016). A framework for computational thinking based on a systematic research review. Baltic J. Modern Computing, 4 (3), 583-596.

Karasar, N. (2016). Bilimsel araştırma yöntemi [Scientific research method]. Nobel Publishing, Ankara.

Korkmaz, Ö., Cakir, R., \& Özden, M. Y. (2017). A validity and reliability study of computational thinking scales (CTS). Computers in Human Behavior, 72, 558-569.

Lee, I., Martin, F., Denner, J., Coulter, B., Allan, W., Erickson, J., \& Werner, L. (2011). Computational thinking for youth in practice. Acm Inroads, 2(1), 32-37.

Magana, A. J., \& Silva Coutinho, G. (2017). Modeling and simulation practices for a computational thinking-enabled engineering workforce. Computer Applications in Engineering Education, 25(1), 62-78.

Mannila, L., Dagiene, V., Demo, B., Grgurina, N., Mirolo, C., Rolandsson, L., \& Settle, A. (2014). Computational thinking in K-9 education. In A. Clear and R. Lister (Eds.), Proceedings of the working group reports of the 2014 on innovation \& technology in computer science education conference, 1-29. ACM.

Milles, M. B., \& Huberman, A. M. (1994). An expanded sourcebook: Qualitative data analysis. Sage, London.

Nouri, J., Zhang, L., Mannila, L., \& Norén, E. (2020). Development of computational thinking, digital competence and 21st century skills when learning programming in K-9. Education Inquiry, 11(1), 1-17.

Oluk, A., Korkmaz, Ö., \& Oluk, H. A. (2018). Scratch'ın 5. sınıf öğrencilerinin algoritma geliştirme ve bilgi-işlemsel düşünme becerilerine etkisi [Effect of scratch on 5th graders' algorithm development and computational thinking skills]. Turkish Journal of Computer and Mathematics Education, 9(1), 54-71.

Özçinar, H. (2017). Hesaplamalı düşünme araştırmalarının bibliyometrik analizi [Bibliometric analysis of computational thinking research]. Eğitim Teknolojisi Kuram ve Uygulama, 7(2), 149-171.

Özkeș, B. (2016). Bilişimsel düşünme temelli ders etkinliklerinin öğrencilerin eleștirel düşünme becerileri ve problem çözme becerilerine yönelik algıları üzerine etkisinin incelenmesi [The effects of course activities based computational thinking on critical thinking skills and problem solving skills perceptions]. (Unpublished Masters' thesis). Mevlana University, Konya.

Pérez-Marín, D., Hijón-Neira, R., Bacelo, A., \& Pizarro, C. (2020). Can computational thinking be improved by using a methodology based on metaphors and scratch to teach computer programming to children? Computers in Human Behavior, 105, 84-99.

Portelance, D. J., \& Bers, M. U. (2015, June). Code and Tell: Assessing young children's learning of computational thinking using peer video interviews with Scratch. Proceedings of the 14th International Conference on Interaction Design and Children, Medford, USA. Retrieved from https://dl.acm.org/doi/pdf/10.1145/2771839.2771894

Riley, D. D., \& Hunt, K. A. (2014). Computational thinking for the modern problem solver. Boca Raton, FL: CRC Press. 
Snalune, P. (2015). The benefits of computational thinking. ITNOW, 57(4), 58-59.

Şahiner, A., \& Kert, S. B. (2016). Examining studies related with the concept of computational thinking between the years of 2006-2015. European Journal of Science and Technology, 5(9), 38-43.

Şimşek, N., \& Yaşar, A. (2019). GeoGebra ile ilgili lisansüstü tezlerin tematik ve yöntemsel eğilimleri: Bir içerik analizi [A thematic and methodological review of theses related to GeoGebra: A content analysis]. Turkish Journal of Computer and Mathematics Education, 10(2), 290-313.

Tang, K. Y., Chou, T. L., \& Tsai, C. C. (2020). A content analysis of computational thinking research: An international publication trends and research typology. The Asia-Pacific Education Researcher, 29(1), 9-19.

Tosik-Gün, E., \& Güyer, T. (2019). Bilgi işlemsel düşünme becerisinin değerlendirilmesine ilişkin sistematik alanyazın taraması [A systematic literature review on assessing computational thinking]. Ahmet Keleşoğlu Eğitim Fakültesi Dergisi, 1(2), 99-120.

Üzümcü, Ö. ve Bay, E. (2018). Eğitimde yeni 21. yüzyıl becerisi: Bilgi işlemsel düşünme [A new 21st century skill in education: Computational thinking]. Uluslararası Türk Kültür Coğrafyasında Sosyal Bilimler Dergisi, 3(2), 1-16.

Weinberg, A. E. (2013). Computational thinking: An investigation of the existing scholarship and research. Unpublished Doctoral Dissertation, Colorado State University, Colorado, USA.

Wing, J. M. (2008). Computational thinking and thinking about computing. Philosophical Transactions of the Royal Society A: Mathematical, Physical and Engineering Sciences, 366(1881), 3717-3725.

Wong, K. W. G., Chıng, C. C., Mark, K. P., Tang, J. K., Lei, C. U., Cheung, H. Y., \& Chuı, H. L. (2015). Impact of computational thinking through coding in K-12 education: A pilot study in Hong Kong. General Studies, 85(88), 2-8. 


\section{Appendixs}

Graduate theses and codes analyzed within the scope of this study

\begin{tabular}{ll}
\hline Kod & Master's \\
\hline M1 & Çakır, E. (2017). Ters yüz sınıf uygulamalarının fen bilimleri 7.sınıf öğrencilerinin akademik başarı, zihinsel
\end{tabular}
risk alma ve bilgisayarca düșünme becerileri üzerine etkisi (Yayınlanmamıș yüksek lisans tezi). Ondokuz Mayıs Üniversitesi, Eğitim Bilimleri Enstitüsü, Samsun.

M2 Oluk, A. (2017). Öğrencilerin bilgisayarca düşünme becerilerinin mantıksal matematiksel zeka ve matematik akademik başarıları açısından incelenmesi (Yayınlanmamış yüksek lisans tezi). Amasya Üniversitesi, Fen Bilimleri Enstitüsü, Amasya.

M3 Erdem, E. (2018). Blog tabanlı ortamlarda programlama öğretimi sürecinde farklı öğretim stratejilerinin çeşitli değişkenler açısından incelenmesi (Yayınlanmamış yüksek lisans tezi). Başkent Üniversitesi, Eğitim Bilimleri Enstitüsü, Ankara.

M4 Yolcu, V. (2018). Programlama eğitiminde robotik kullanımının akademik bașarı, bilgi-ișlemsel düșünme becerisi ve öğrenme transferine etkisi (Yayınlanmamış yüksek lisans tezi). Süleyman Demirel Üniversitesi, Eğitim Bilimleri Enstitüsü, Isparta.

M5 Şimşek, E. (2018). Programlama öğretiminde robotik ve scratch uygulamalarının öğrencilerin bilgi işlemsel düşünme becerileri ve akademik başarılarına etkisi (Yayınlanmamış yüksek lisans tezi). Ondokuz Mayıs Üniversitesi, Eğitim Bilimleri Enstitüsü, Samsun.

M6 Akkaya, A. (2018). Eğitsel oyunların öğrencilerin nesne tabanlı programlamanın temel kavramsal bilgisi ve bilgi işlemsel düşünme becerilerine etkisi (Yayınlanmamış yüksek lisans tezi). Boğaziçi Üniversitesi, Sosyal Bilimleri Enstitüsü, İstanbul.

M7 Çatana-Kuleli, S. (2018). Öğretmen adaylarının çevrimiçi öğrenmeye hazırbulunuşluk düzeyleri ve bilgi işlemsel düşünme becerilerinin değerlendirilmesi (Yayınlanmamış yüksek lisans tezi). Düzce Üniversitesi, Sosyal Bilimleri Enstitüsü, Düzce.

M8 Özyol, B. (2019). Bilgi-Işslemsel düşünme becerisinin kazandırılmasına yönelik bir ortam tasarımı ve geliştirilmesi (Yayınlanmamış yüksek lisans tezi). Afyon Kocatepe Üniversitesi, Fen Bilimleri Enstitüsü, Afyon Kocatepe.

M9 Turan, B. (2019). Ortaokul öğrencilerinin geliştirdiği oyun ve robot projelerinde probleme dayalı öğrenmenin problem çözme ve bilgi işlemsel düşünme becerilerine etkisi (Yayınlanmamış yüksek lisans tezi). Van Yüzüncü Yıl Üniversitesi, Eğitim Bilimleri Enstitüsü, Van.

M10 Çimentepe, E. (2019). Stem etkinliklerinin akademik başarı, bilimsel süreç becerileri ve bilgisayarca düşünme becerilerine etkisi (Yayınlanmamış yüksek lisans tezi). Niğde Ömer Halisdemir Üniversitesi, Eğitim Bilimleri Enstitüsü, Niğde.

M11 Uğur, N. (2019).Bilgisayarsız ortamda bilgisayar bilimi öğretiminde yansıtıcı düşünme etkinliklerinin bilgi işlemsel düşünme becerileri geliştirmede etkisi (Yayınlanmamış yüksek lisans tezi). Trabzon Üniversitesi, Lisansüstü Eğitim Enstitüsü, Trabzon.

M12 Uysal, Y. (2019). Blok tabanlı görsel programlamanın matematiksel problem çözme ve hesaplamalı düşünme üzerine etkileri (Yayınlanmamış yüksek lisans tezi). Boğaziçi Üniversitesi, sosyal Bilimler Enstitüsü, İstanbul.

M13 Karaahmetoğlu, K. (2019).Proje tabanlı arduino eğitsel robot uygulamalarının öğrencilerin bilgisayarca düşünme becerileri ve temel stem beceri düzeyleri algılarına etkisi (Yayınlanmamış yüksek lisans tezi). Amasya Üniversitesi, Fen Bilimleri Enstitüsü, Amasya.

M14 Çetinkaya, H. N. (2019).Bilişim teknolojileri ve yazılım dersindeki etkinliklerin bilgi işlemsel düşünme ve bazı değişkenler açısından incelenmesi (Yayınlanmamış yüksek lisans tezi). İnönü Üniversitesi, Eğitim Bilimleri Enstitüsü, Malatya.

M15 Ergin, H. (2019).Programlama dersinde proje kullanımının öğrencilerin bilgi işlemsel düşünme becerilerine ve programlama öz yeterlilik inancına etkisi (Yayınlanmamış yüksek lisans tezi).Ege Üniversitesi, Fen Bilimleri Enstitüsü, İzmir.

M16 Çelik-Kırçalı, A. (2019). K12 Düzeyinde algoritma öğretiminde kullanılan bilgisayarlı ve bilgisayarsız araçların çeşitli değişkenler açısından değerlendirilmesi (Yayınlanmamış yüksek lisans tezi).Marmara Üniversitesi, Eğitim Bilimleri Enstitüsü, İstanbul.

M17 Huruzoğluı, N. (2019). Kısa süreli bir eğitimin öğrenci ve öğretmenlerin bilgi-işlemsel düşünme, programlama ve girişimcilik özyeterlik algıları üzerindeki etkisi (Yayınlanmamış yüksek lisans tezi).Orta Doğu Teknik Üniversitesi, Fen Bilimleri Enstitüsü, Ankara.

M18 Paf, M. (2019). Ortaokul öğrencilerinin bilişimsel düşünme becerileri ile yaratıcı problem çözme becerileri arasındaki ilişki (Yayınlanmamış yüksek lisans tezi). Aydın Adnan Menderes Üniversitesi, Sosyal Bilimler Enstitüsü, Aydın.

M19 Delal, H. (2019). Ortaokul öğrencilerinin bilgi işlemsel düşünme becerilerinin bilgisayarsız bilgisayar bilimi (b3) etkinlikleri ile geliştirilmesi (Yayınlanmamış yüksek lisans tezi). Boğaziçi Üniversitesi, Sosyla Bilimler Enstitüsü, İstanbul. 
M20 Tutulmaz, M. (2019). Bilgi-işlemsel düşünme becerisinin geliştirilmesine yönelik veri görselleştirmenin tasarlanması, uygulanması ve değerlendirilmesi (Yayınlanmamış yüksek lisans tezi). Hacettepe Üniversitesi, Eğitim Bilimleri Enstitüsü, Ankara.

M21 Karakaş, E. (2019). Bilgi işlemsel düşünme becerilerinin makina öğrenmesi kullanarak performansa dayalı değerlendirilmesi (Yayınlanmamıș yüksek lisans tezi). İstanbul Okan Üniversitesi, Fen Bilimleri Enstitüsü, İstanbul.

M22 Kuleli, S. (2019). 8. Sınıf öğrencilerinin bilgi işlemsel düşünme becerilerine yönelik özyeterlilik algılarının incelenmesi (Yayınlanmamış yüksek lisans tezi).Ege Üniversitesi, Eğitim Bilimleri Enstitüsü, İzmir.

M23 Özel, 0. (2019). Programlama yöntemlerinin ortaokul öğrencilerinin bilgi işlemsel düşünme becerisine yönelik öz yeterlik algısına ve programlama başarısına etkisi (Yayınlanmamış yüksek lisans tezi). Marmara Üniversitesi, Eğitim Bilimleri Enstitüsü, İstanbul.

M24 Dağlı, Z. (2019). Bilişim teknolojileri öğretmenlerinin bilgisayar bilimi dersi "problem çözme ve algoritmalar" ünitesinde öğrencilerin bilgi-işlemsel düşünme becerilerini geliştirmek için tasarladıkları öğretim tasarımı sürecinin incelenmesi (Yayınlanmamış yüksek lisans tezi). Mersin Üniversitesi, Eğitim Bilimleri Enstitüsü, Mersin.

M25 Serim, E. (2019). Oyunlaștırma yöntemiyle tasarlanan kodlama eğitimi ile öğrencilerin hesaplamalı düşünme becerileri ve kodlamaya ilişkin öz-yeterlik algılarının incelenmesi (Yayınlanmamış yüksek lisans tezi). Balıkesir Üniversitesi, Fen Bilimleri Enstitüsü, Balıkesir.

M26 Bal, N. (2019). Temel robotik eğitiminin ortaokul öğrencilerinin 21. yüzyıl becerilerine ve bilgi işlemsel düşünme becerilerine etkisi (Yayınlanmamış yüksek lisans tezi). Hatay Mustafa Kemal Üniversitesi, Fen Bilimleri Enstitüsü, Hatay.

M27 Kocabıyık, N. (2019). Bilgisayarsız ortamda bilgisayar bilimi öğretiminde yansıtıcı düşünme etkinliklerinin bilgi işlemsel düşünme becerileri geliştirmede etkisi (Yayınlanmamış yüksek lisans tezi). Trabzon Üniversitesi, Lisansüstü Eğitim Enstitüsü, Trabzon.

M28 Ușengül, L. (2019). Lego wedo 2.0 eğitiminin öğrenenlerin fen bilimlerine yönelik akademik başarı ve tutumları ile bilgi işlemsel düşünme becerilerine etkisi (Yayınlanmamış yüksek lisans tezi). Fırat Üniversitesi, Eğitim Bilimleri Enstitüsü, Elazığ.

M29 Şenol, Ş. (2019). İlkokulda kodlama eğitimi: sınıf öğretmenleri örneği (Yayınlanmamış yüksek lisans tezi). Süleyman Demirel Üniversitesi, Eğitim Bilimleri Enstitüsü, Isparta.

M30 Altun, H. (2017). Teknolojik pedagojik alan bilgisi (tpac) çerçevesi ile oluşturulmuş programlama eğitiminin öğrenme çıktıları üzerine etkileri (Yayınlanmamış yüksek lisans tezi). Necmettin Erbakan Üniversitesi, Eğitim Bilimleri Enstitüsü, Konya.

D1 Taş, N. (2018). Farklılaştırılmış bilgisayar destekli matematik etkinliklerinin üstün yeteneklilerin bilgi işlemsel düşünme öz yeterlikleri ve matematiğe yönelik tutumlarına etkisi (Yayınlanmamış Doktora tezi). Atatürk Üniversitesi, Eğitim Bilimleri Enstitüsü, Erzurum.

D2 Berikan, B. (2018). Bilgi işlemsel düşünme becerisine yönelik tasarlanan "veri setleriyle problem çözme" öğrenme deneyiminin biçimlendirici değerlendirmesi (Yayınlanmamış Doktora tezi). Gazi Üniversitesi, Eğitim Bilimleri Enstitüsü, Ankara.

D3 Kukul, V. (2018). Programlama öğretiminde farklı yapılandırılan süreçlerin öğrencilerin bilgi işlemsel düşünme becerilerine, öz yeterliliklerine ve programlama başarılarına etkisi (Yayınlanmamıș Doktora tezi). Gazi Üniversitesi, Eğitim Bilimleri Enstitüsü, Ankara.

D4 Üzümcü, Ö. (2019). Bilgi işlemsel düşünme becerisine yönelik program tasarımının geliştirilmesi ve etkililiğinin değerlendirilmesi (Yayınlanmamış Doktora tezi). Gaziantep Üniversitesi, Eğitim Bilimleri Enstitüsü, Gaziantep.

D5 Atiker, B. (2019). Programlama öğretiminde ortaokul öğrencilerinin bilgi işlemsel düşünme becerilerinin başarıya etkileri (Yayınlanmamış Doktora tezi). İstanbul Üniversitesi, Fen Bilimleri Enstitüsü, İstanbul.

D6 Ceylan, V. K. (2020). Senaryo temelli scratch öğretim programının öğrencilerin bilgi işlemsel düşünme becerilerine, problem çözme ve programlama ünitesi erişilerine etkisi (Yayınlanmamış Doktora tezi). Aydın Adnan Menderes Üniversitesi, Sosyal Bilimler Enstitüsü, Aydın.

D7 Avcu, Y.E. (2019). Özel yetenekli öğrenciler için bilişim teknolojileri ve yazılım alanına yönelik bir öğretim tasarımının geliştirilmesi (Yayınlanmamış Doktora tezi). Balıkesir Üniversitesi, Sosyal Bilimler Enstitüsü, Balıkesir.

D8 Çetin, E. (2016). Okul öncesi çocukların problem çözme sürecinde teknoloji destekli şematik düzenleyicilerin kullanımına yönelik bir durum çalışması (Yayınlanmamış Doktora tezi). Gazi Üniversitesi, eğitim Bilimleri Enstitüsü, Ankara. 
In the writing process of the study titled "Thematic and Methodological Trends of Computational Thinking Skills-Related Graduate Theses in Turkey", the rules of scientific, ethical and citation were followed; it was undertaken by the authors of this study that no falsification was made on the collected data. "Sakarya University Journal of Education Journal and Editor" had no responsibility for all ethical violations to be encountered, and all responsibility belongs to the authors and that the study was not submitted for evaluation to any other academic publishing environment. 


\title{
Türkiye'de Bilgi İşlemsel Düşünme Becerisi ile İlgili Yapılmış Lisansüstü Tezlerin Tematik ve Yöntemsel Eğilimleri
}

\author{
Mithat ELÇíçEK*
}

\begin{abstract}
Öz. Bu araştırmanın amacı, Türkiye'de bilgi işlemsel düşünme becerisi ile ilgili yapılmış lisansüstü tezlerin tematik ve yöntemsel açıdan analizlerini yapmaktır. $\mathrm{Bu}$ amaç kapsamında YÖK (Yükseköğretim Kurulu) Ulusal Tez Merkezi veri tabanında yer alan Nisan 2020'e kadar yayınlanmış 30 yüksek lisans ve 8 doktora olmak üzere toplam 38 eser nitel araştırma yöntemlerinden doküman incelemesi modeli kullanılarak incelenmiştir. Lisansüstü tezlerin incelenmesinde betimsel içerik analizi tekniği kullanılmıştır. Araştırma sonuçlarına göre lisansüstü tezlerde daha çok programlama öğretimi, robotik ve blok tabanlı görsel programlamanın bilgi işlemsel düşünme becerisi üzerindeki etkilerinin incelendiği sonucuna ulaşılmıştır. Oldukça sınırlı sayıda bilgi işlemsel düşünme becerisinin geliştirilmesine yönelik tasarım ve geliştirme çalışmasının yapıldığı tespit edilmiştir. Lisansüstü tezlerin büyük çoğunluğunun Bilgisayar ve Öğretim Teknolojileri Eğitimi alanında yapıldığı ve en fazla tezin 2019 yılında yayınlandığı görülmüştür. Lisansüstü tezlerin daha çok nicel araştırma yöntemi ve yarı deneysel desen kullanılarak tasarlandığı, çalışmalarda çoğunlukla ortaokul örneklem profilinin tercih edildiği sonucuna ulaşılmıştır. Bununla birlikte ağırlıklı olarak ölçek, görüşme ve gözlem veri toplama araçları kullanılarak toplanan verilerin kestirimsel analiz teknikleri doğrultusunda analiz edildiği görülmüştür. Araştırma sonucunda, nitel veya karma araştırma yöntemlerinin kullanıldığı, özellikle okul öncesi örneklem profilinin tercih edildiği tasarım çalışmalarının yapılması önerilmiştir.
\end{abstract}

Anahtar Kelimeler: Bilgi işlemsel düşünme, lisansüstü tezler, içerik analizi.

\footnotetext{
${ }^{*}$ Orcid ID: https://orcid.org/0000-0003-1845-7271, Dr., Siirt Üniversitesi, Türkiye, mithatelcicek@gmail.com
} 


\section{GİRIŞ}

Sanayi toplumundan bilgi toplumuna geçiş sürecinin yaşandığı günümüzde, teknoloji üretimine dayalı yoğun rekabetlerin yaşandığı küresel bir yarış başlamıştır. Toplumların bu küresel yarıştan etkin bir mücadeleyle çıkabilmesi, toplumu oluşturan bireylerin bilgi ve iletişim yeterlilikleriyle doğrudan ilgilidir (Tosik-Gün ve Güyer, 2019). Çünkü teknolojiyi yalnızca tüketen bireylerden oluşan toplumların bu yarışta etkin bir yer alması beklenemez. Dolayısıyla toplumlar ihtiyaç duyduğu insan profili için başta eğitim politikaları olmak üzere pek çok alanda reformlar gerçekleştirmiştir (Israel, Pearson, Tapia, Wherfel ve Reese, 2015; Mannila vd., 2014; Wong vd., 2015). Yapılan reformlarda etkin problem çözme becerisiyle donatılmış, karmaşık sistemler tasarlayabilen bireylerin yetiştirilmesi hedeflenmektedir (Tosik-Gün ve Güyer, 2019). Bu bağlamda 21. yüz yıl becerileri olarak tanımlanan bir takım yetkinlikler, toplumların ihtiyacı olan insan profili için dinamik bir çerçeve sunmaktadır (Üzümcü ve Bay, 2018). İş birliği, problem çözme, eleştirel düşünme, analitik düşünme ve tasarım düşünme gibi yetkinlikler içeren bu çerçeveye yakın zamanda bilgi işlemsel düşünme becerisi eklenmiştir (International Society for Technology in Education, 2015). Janette Wing'in 2006 yllında yaptığı çalışmayla popülerleşme süreci başlayan bilgi işlemsel düşünme için farklı bağlamlarda yapılmış pek çok tanım bulunmaktadır (Gonzalez, 2015; Grover ve Pea, 2013; Kalelioğlu, Gülbahar ve Kukul, 2016, Wing, 2008). Bu tanımlardan biri ISTE (International Society for Technology in Education- Uluslararası Eğitim Teknolojileri Topluluğu) ve CSTA (Computer Science Teachers Association- Bilgisayar Bilimi Öğretmenleri Derneği) tarafından yapılmıştır. Yapılan bu tanımda bilgi işlemsel düşünme; bilgisayarlar aracılığıyla düzenleme, çözümleme, formülleştirme, otomatikleştirme, transfer ve genelleştirme işlemlerinin yapıldığı problem çözme süreci olarak açıklanmaktadır (ISTE ve CSTA, 2011). Bir diğer tanım ise Carnegie Mellon Üniversitesi Bilgi İşlemsel Düşünme Merkezi tarafından yapılmıştır. Yapılan tanıma göre bilgi işlemsel düşünme; bilgisayar biliminin temel kavramlarını kullanarak problemi anlama, probleme yönelik etkili çözümler geliştirme ve sistem tasarımı yaklaşımı yoluyla çözümün uygulaması ve genelleştirilmesi sürecidir (Center for Computational Thinking Carnegie Mellon, 2019). Riley ve Hunt (2014) ise bilişsel süreçlere vurgu yaparak, bilgi işlemsel düşünmeyi algoritmik düşünmeye dayalı problem çözme süreci olarak ifade etmektedir. Yapılan tanımlar farklılaşsa da odak noktanın problem çözme ekseninde yapılandırıldığı anlaşılmaktadır.

Problem çözme, sadece belirli bir disiplin veya meslek grubunun değil her kesimden bireyin sahip olması gereken önemli bir beceridir (Care, Scoular ve Griffin, 2016; Griffin, 2017). Özellikle günlük hayatta karşılaşılan problem durumlarının eskiye oranla daha karmaşık bir yapıya dönüşmüş olması yeni çözüm stratejilerine olan ihtiyacı artırmıştır (Griffin, 2017). Bu yeni çözüm stratejilerinden biri de bilgi işlemsel düşünme becerisinin geliştirilmesine yönelik yapılan çalışmalardır (ISTE, 2015). Bilgi işlemsel düşünme becerisiyle, bireyin yaşam başarısının artırılması, iş ve eğitim hayatına daha iyi hazırlanması ve aynı zamanda küresel ölçekte rekabet edebilmesinin sağlanması amaçlanmaktadır (Lee vd., 2011; Snalune, 2015; Wing, 2008). Bu amaca yönelik olarak 
bilgi işlemsel düşünme becerisinin geliştirilmesi için son zamanlarda programlama, robotik, bilgisayar oyunları, simülasyon ve kodlama gibi içeriklerin yoğun olarak kullanıldığı etkinlik ve uygulamalar geliştirilmektedir (Bers, 2010; Magana ve Silva Coutinho, 2017; Oluk, Korkmaz ve Oluk, 2011).

Bilgi işlemsel düşünme becerisinin geliştirilmesi bütün ülkede olduğu gibi Türkiye'de de son dönemlerde araştırmacıların ve politika geliştiricilerinin ilgi odağı haline gelmiştir (Gülbahar ve Kalelioğlu, 2018; Tang, Chou ve Tsai, 2020). Bu kapsamda, bilgi işlemsel düşünme becerisinin geliştirilmesine yönelik yeni ders içerikleri hazırlanmakta ve öğretim programları yenilenmektedir. Örneğin Amerika, Estonya, Güney Kore ve bazı Avrupa Birliği ülkeleri öğretim programlarını güncelleyerek, programlama ve kodlama gibi yeni içerikler eklemişlerdir (Demirer ve Sak, 2016; Gülbahar ve Kalelioğlu, 2018). Türkiye'de de Talim ve Terbiye Kurlu Başkanlığınca “Bilişim Teknolojileri” ders müfredatı yazılım ve kodlama içerikleriyle zenginleştirilmiştir. Benzer şekilde farklı disiplinler için yeni etkinlikler de hazırlanmaya devam etmektedir (Kaan, Çalışkan ve Yetişir, 2017). Ayrıca bilgi işlemsel düşünme becerisiyle ilgili makale, yüksek lisans ve doktora tez çalışmalarında önemli artışların yaşandığı bilinmektedir (İliç, Haseski ve Tuğtekin ,2018; Kalelioğlu, 2018). Tang, Chou ve Tsai (2020) tarafından yapılan araştırmada, bilgi işlemsel düşünme becerisine yönelik 2006-2018 yılları arasında yapılmış çalışmalar incelendiğinde, bilgi işlemsel düşünme becerisine yönelik araştırma sayısında 2013 yılından sonra dikkat çeken artışların yaşandığı gözlemlenmiştir. Benzer şekilde Haseski, Ilic ve Tugtekin, (2018) tarafından Web of Science ve ERİC veri tabanları kullanılarak yapılan içerik analizi çalışmasında bilgi işlemsel düşünme becerisine yönelik yayın sayısının 2010 yılından sonra iki kattan fazla artığı tespit edilmiştir. Türkiye ile ilgili dünya ölçeğinde yapılan araştırma sonuçlarına bakıldığında ise 2010 ile 2020 yılları arasındaki yayın sayısı sıralamasında ilk 10'da olduğu görülmektedir (Tang, Chou ve Tsai, 2020).

Yapılan araştırmalar gösteriyor ki Türkiye'de son yıllarda bilgi işlemsel düşünme becerisiyle ile ilgili yapılan çalışmaların sayısında dikkat çeken bir artış gözlemlenmektedir (İliç, Haseski ve Tuğtekin, 2018; Kalelioğlu, 2018). Bu bağlamda, bilgi işlemsel düşünme becerisiyle ilgili yapılan çalışmalara yönelik eğilim, boşluk ve yı̆̆ılmaları belirlemede genel bir çerçeve sağlayacak araştırmalara ihtiyaç duyulmaktadır. Türkiye'de bilgi işlemsel düşünme becerisiyle ilgili çalışmaların incelendiği sınırlı sayıda araştırmaya rastlanmıştır (Haseski, Ilic ve Tugtekin, 2018; Kalelioğlu, 2018; Kalelioğlu, Gülbahar ve Kukul, 2016; Tosik-Gün ve Güyer, 2019). Bununla birlikte bilgi işlemsel düşünme becerisiyle ilgili hazırlanmış lisansüstü tezlerin incelendiği herhangi bir çalışmaya rastlanmamıştır. Türkiye'deki bilgi işlemsel düşünme becerisiyle ilgili hazırlanmış lisansüstü tezlerin yoğunluğu göz önünde bulundurulduğunda bu tezlere yönelik eğilimleri, boşlukları veya yığılmaları, bütüncül bir bakış açısıyla inceleyecek içerik analizi çalışmalarına ihtiyaç olduğu düşünülmektedir. Türkiye'deki bilgi işlemsel düşünme becerisi ile ilgili yapılmış tezlerin incelenerek genel bir çerçevenin sunulması, ilgili alanda çalışacak araştırmacılara yol göstermesi açısından önemlidir. Bu çerçevede araştırmanın amacı, Türkiye'deki bilgi işlemsel düşünme becerisi ile ilgili yapılmış 
lisansüstü tezlerin tematik ve yöntemsel eğilimlerinin incelenmesidir. Tematik açıdan tezlerin amaç ve problem cümleleri, bilim dallarına göre dağılımı ve yayınlanma yılları incelenirken, yöntemsel olarak ise lisansüstü tezlerin araştırma yöntemleri, desenleri, örneklem profili, veri toplama araçları ve veri analiz teknikleri incelenmiştir. Bu sayede çalışmaların benzerlikleri ve farklılıkları ortaya konularak genel bir çerçeve sunulması ve bu alanda çalışma yapacak araştırmacılara yol göstermesi hedeflenmektedir. Bu kapsamda aşağıdaki araştırma sorularına cevap aranmıştır.

1. Türkiye'de bilgi işlemsel düşünme becerisi ile ilgili yapılmış lisansüstü tezlerin tematik açıdan genel özellikleri nelerdir?

a. Lisansüstü tezlerde hangi konular incelenmiştir?

b. Bilim dallarına göre dağılımları nasıldır?

c. Yayınlanma yıllarına göre dağılımları nasıldır?

2. Türkiye'de bilgi işlemsel düşünme becerisi ile ilgili yapılmış lisansüstü tezlerin yöntemsel açıdan genel özellikleri nelerdir?

a. Lisansüstü tezlerde hangi araştırma yöntemleri kullanılmıştır?

b. Hangi araştırma modeli veya desenleri tercih edilmiştir?

c. Örneklem profilleri nasıldır?

d. Hangi veri toplama araçları kullanılmıştır?

e. Lisansüstü tezlerde kullanılan veri analiz teknikleri nelerdir?

\section{YÖNTEM}

$\mathrm{Bu}$ çalışma, izlediği süreç bakımından nitel araştırma yöntemlerinden doküman incelemesi modeli kullanılarak tasarlanmıştır. Doküman incelemesi, araştırılması planlanan yazılı kaynakların sistemli olarak analiz edilmesinde sıklıkla kullanılan bir araştırma yöntemidir (Karasar, 2016). Çalışma kapsamında Nisan 2020'e kadar yayınlanmış bilgi işlemsel düşünme becerisi ile ilgili lisansüstü tezler tematik ve metodolojik açıdan incelenmiştir. İlgili lisansüstü tezlerin analizindeki temel amaç, bilgi işlemsel düşünme becerisi alanındaki eğilimlerin, boşlukların veya yığılmaların ortaya çıkarılmasıdır. Bu amaca yönelik olarak çalışmada betimsel içerik analizi deseni kullanılmıştır. Betimsel içerik analizi, daha önceden yayınlanmış eserler hakkında önceden belirlenmiş bir çerçeveye bağlı olarak özet bilgiler elde etmek veya genel bir görüntü sunmak için kullanılan bir yöntemdir (Büyüköztürk vd., 2008; Çalık ve Sözbilir, 2014). Betimsel içerik analizi, verilerin toplanmasını ve verilerin analizini kapsayan adımlardan oluşmaktadır. Bu kapsamda mevcut araştırmada veri tabanı taraması yoluyla önce veriler toplanmış ve ardından bu veriler araştırma sorularına göre analiz edilerek yorumlanmıştır. 


\section{Verilerin Toplanması}

Araştırmanın örneklemi, YÖK (Yükseköğretim Kurulu) Ulusal Tez Merkezi veri tabanında yer alan ve Nisan 2020'e kadar yayınlanmış olan bilgi işlemsel düşünme becerisi ile ilgili lisansüstü tezler oluşturmaktadır. Bu nedenle herhangi bir tarih aralığı sınırlaması yapmak yerine araştırmanın yapıldığı Nisan 2020 tarihine kadar yayınlanmış olan bütün lisansüstü tezler çalışmaya dâhil edilmiştir. Veri tabanı taramasında kullanılan anahtar kelimeler, ilgili alanyazın doğrultusunda bilgi işlemsel düşünme kavramı için kullanılan kelimelerden oluşmaktadır. Alanyazın incelemesinde kompütasyonel düşünme (Şahiner ve Kert, 2016), bilgisayarca düşünme (Korkmaz, Çakır ve Özden, 2015), bilişimsel düşünme (Özkeş, 2016), bilgisayımsal düşünme (Çınar ve Tüzün, 2017) ve hesaplamalı düşünme (Özçınar, 2017) ifadelerinin kullanıldığı görülmüştür. Bu kapsamda ulusal tez merkezi veri tabanında bu anahtar kelimelerin her biri için tarih ve alan kısıtlaması yapılmaksızın sorgular gerçekleştirilmiş ve ilgili eserlere ulaşılmıştır. Yapılan sorgularda bilgi işlemsel düşünme için 43 , kompütasyonel düşünme için 0 , bilgisayarca düşünme için 14, bilişimsel düşünme için 3, bilgisayımsal düşünme için 0 ve hesaplamalı düşünme için 3 olmak üzere toplam 63 sonuç elde edilmiştir. Yapılan ön incelemede bilgi işlemsel düşünme becerisiyle ilgili olmayan 13 çalışma, erişime kapalı 2 ve mükerrer 10 çalışma çıkarıldıktan sonra 30 yüksek lisans ve 8 doktora olmak üzere toplam 38 lisansüstü tezi araştırma kapsamında incelenmiştir (Bakınız Ek-1). Tezlerin incelenmesinde daha önce yapılan benzer çalışmalar ekseninde araştırmacı tarafından hazırlanan form kullanılmıştır. Bu form tematik ve yöntemsel olmak üzere iki bölümden oluşmaktadır. Tematik bölümde tezde çalışılan konu, tezin hazırlandığı bilim dalı, tezin yayınlandığı yıl bilgileri tutulmaktadır. Yöntemsel bölümde ise araştırmanın yöntemi, deseni, örneklemi, kullanılan veri toplama araçları ve araştırmanın analiz yöntemi bilgileri tutulmaktadır.

\section{Verilerin Analizi}

Verilerin analizi sürecinde Şimşek ve Yaşar'ın (2019) çalışmalarında izledikleri doküman incelmesi aşamaları takip edilmiştir. Birinci aşamada, tezler yüksek lisans ve doktora olarak iki klasör halinde bilgisayara kaydedilmiştir. Yüksek lisans tezlerinden başlayarak Ulusal Tez Merkezi tarafından verilen tez numarası sırasına göre her birine birer kod verilmiştir. Analiz ve bulguların sunumunda bu kodlar kullanılmıştır. İkinci aşamada, her bir araştırma problemine yönelik elde edilen veriler tezin koduyla birlikte bir Excel sayfasına girilmiştir. Üçüncü aşamada, Excel sayfasındaki veriler ayrıntılı bir şekilde incelenerek tablolar hazırlanmıştır. Dördüncü ve son aşamada ise veriler araştırma soruları çerçevesinde tablolarda frekanslarıyla birlikte sunulmuştur.

Verilerin analizinin güvenirliğini sağlamak için verilerin Excel'e girilmesi ve kodlanması aşaması, yazarla birlikte bir uzman tarafından gerçekleştirilmiştir. Kodlayıcılar arasındaki uzlaşma yüzdesi için Miles ve Huberman (1994) tarafından önerilen, Güvenirlik katsayısı = [Görüş birliği / (Görüş birliği + Görüş ayrılı̆̆ı)]x100 formülü kullanılmıştır. Güvenirlik katsayısı 0,84 olarak hesaplanmıştır. Görüş birliğinin sağlanamadığı kodlamalarda kodlayıcılar bir araya gelerek uzlaşma sağlanmıştır. Araştırmanın geçerliliğini sağlamak için ise verilerin analizi sürecinde her iki kodlayıcı 
tarafından tezler ayrıntılı ve derinlemesine incelenmiştir. Elde edilen veriler kodlarıyla birlikte tablolar halinde sunulmuştur.

\section{BULGULAR}

Araştırma kapsamında elde edilen bulgular iki bölüm halinde sunulmuştur. Birinci bölümde bilgi işlemsel düşünme becerisine yönelik yapılmış lisansüstü tezlerin tematik açıdan genel özelileri, ikinci bölümde ise yöntemsel açıdan genel özellikleri incelenmiştir.

Türkiye'de bilgi işlemsel düşünme becerisine yönelik yapılmış lisansüstü tezlerin tematik açıdan genel özellikleri

$\mathrm{Bu}$ bölümde lisansüstü tezlerde hangi konuların ele alındığg, bilim dallarına göre dağılımları ve lisansüstü tezlerin yayınlanma yılları ile türleri hakkında bilgiler sunulmuştur. Lisansüstü tezlerde ele alınan konulara ilişkin bilgiler Tablo 1'de verilmiştir.

Tablo 1

Lisansüstü Tezlerde Ele Alınan Konular

\begin{tabular}{|c|c|c|c|c|}
\hline $\begin{array}{l}\text { Konular } \\
\text { Çeşitli } \\
\text { değişkenlerin } \\
\text { BİD becerisi } \\
\text { üzerindeki } \\
\text { etkilerinin } \\
\text { incelenmesi }\end{array}$ & \multirow{4}{*}{$\begin{array}{ll}\text { - } & \text { Proje tabanlı öğrenme } \\
\text { yöntemi } \\
\text { • } & \text { Ters yüz sınıf uygulaması } \\
\text { - } & \text { Teknoloji destekli şematik } \\
& \text { düzenleyiciler }\end{array}$} & \multirow{2}{*}{$\begin{array}{c}\text { Yüksek lisans } \\
\text { Y15, Y13* }\end{array}$} & \multirow[t]{2}{*}{ Doktora } & \multirow{2}{*}{$\begin{array}{l}\mathrm{f} \\
2\end{array}$} \\
\hline \multirow{10}{*}{$\begin{array}{l}\text { Çeşitli } \\
\text { değişkenlerin } \\
\text { BİD becerisi } \\
\text { üzerindeki } \\
\text { etkilerinin } \\
\text { incelenmesi }\end{array}$} & & & & \\
\hline & & Y1, Y3 & & 2 \\
\hline & & & D8* $^{*}$ & 1 \\
\hline & $\begin{array}{l}\text { - Probleme dayalı öğrenme } \\
\text { yöntemi }\end{array}$ & Y9 & & 1 \\
\hline & $\begin{array}{l}\text { - Yansitıcı düşünme } \\
\text { etkinlikleri }\end{array}$ & Y11, Y27 & & 2 \\
\hline & - Eğitsel oyunlar & Y6 & & 1 \\
\hline & $\begin{array}{l}\text { - Öğrenme sürecinin } \\
\text { oyunlaştırılması }\end{array}$ & Y25 & & 1 \\
\hline & $\begin{array}{l}\text { - Bilgisayar destekli } \\
\text { matematik etkinlikleri }\end{array}$ & & D1 & 1 \\
\hline & $\begin{array}{l}\text { - Balık kılçı̆̆ı, beyin fırtınası } \\
\text { ve akış şeması gibi şematik } \\
\text { düzenleyiciler }\end{array}$ & & D8 & 1 \\
\hline & $\begin{array}{l}\text { Bilişim Teknolojileri ve } \\
\text { Yazılım dersindeki } \\
\text { etkinlikler }\end{array}$ & $\mathrm{Y} 14, \mathrm{Y} 17, \mathrm{Y} 19^{*}$ & & 3 \\
\hline
\end{tabular}




\begin{tabular}{|c|c|c|c|c|}
\hline & - $\quad$ Programlama öğretimi & $\begin{array}{c}\mathrm{Y} 3, \mathrm{Y}^{*}, \mathrm{Y} 9, \mathrm{Y} 16^{*} \\
\mathrm{Y}^{2} 3^{*}\end{array}$ & D3, D5* & 7 \\
\hline & - Bilgisayarsız programlama & Y16, Y23, Y19 & & 3 \\
\hline & - Blok tabanlı programlama & Y12, Y29, Y30 & D6 & 4 \\
\hline & - Robot destekli programlama & Y5 & & 1 \\
\hline & $\begin{array}{l}\text { - Eğitsel robotik set } \\
\text { kullanılması }\end{array}$ & Y4, Y13, Y26, Y28 & & 4 \\
\hline & $\begin{array}{l}\text { - STEM eğitimine dayalı } \\
\text { etkinlikler }\end{array}$ & Y10 & & 1 \\
\hline $\begin{array}{l}\text { Çeşitli } \\
\text { değişkenler ile }\end{array}$ & $\begin{array}{l}\text { - Yaratıcı problem çözme } \\
\text { becerisi }\end{array}$ & Y18 & & 1 \\
\hline $\begin{array}{l}\text { BİD becerisi } \\
\text { arasındaki }\end{array}$ & $\begin{array}{l}\text { - Mantıksal matematiksel } \\
\text { zekâ özalgısı }\end{array}$ & $\mathrm{Y} 2^{*}$ & & 1 \\
\hline incelenmesi & - Akademik bașarı & $\mathrm{Y} 2, \mathrm{Y} 22$ & & 2 \\
\hline & $\begin{array}{l}\text { - Çevrimiçi öğrenmeye } \\
\text { hazırbulunuşluk }\end{array}$ & Y7 & & 1 \\
\hline $\begin{array}{l}\text { BID becerisinin } \\
\text { geliştirilmesine }\end{array}$ & $\begin{array}{l}\text { - Veri görselleştirme } \\
\text { uygulaması }\end{array}$ & Y20 & & 1 \\
\hline yönelik & • Öğrenme ortamı & Y8 & & 1 \\
\hline geliștirme & - Öğretim tasarımı & Y24 & D7 & 2 \\
\hline çalışmaları & - Program tasarımı & & D4 & 1 \\
\hline & - Etkinlik & & D2, D5 & 2 \\
\hline $\begin{array}{l}\text { BID becerisinin } \\
\text { performansa da }\end{array}$ & $\begin{array}{l}\text { nakina öğrenmesi kullanarak } \\
\text { ralı değerlendirilmesi }\end{array}$ & Y21 & & 1 \\
\hline Toplam & & & & 48 \\
\hline
\end{tabular}

*Birden fazla tema içeren çalışmalar.

Lisansüstü tezlerin temaları belirlenirken çalışmaların amacı ve problem cümleleri incelenerek çalışmaların odak noktalarına göre temalar belirlenmiştir. Bu kapsamda Tablo 1 incelendiğinde en fazla çalışmanın, çeşitli değişkenlerin BİD becerisi üzerindeki etkilerinin incelendiği (f:35) çalışma temalarında olduğu görülmektedir. Bu çalışmaları sırasıyla BİD becerisinin geliştirilmesine yönelik tasarım ve geliştirme çalışmaları (f:7), çeşitli değişkenler ile BİD becerisi arasındaki ilişkinin incelendiği çalışmalar (f:5) takip etmektedir. Bununla birlikte en az çalışmanın BİD becerisinin makina öğrenmesi kullanarak performansa dayalı değerlendirilmesi (f:1) temasında gerçekleştiği görülmektedir. 
Çeșitli değişkenlerin BİD becerisi üzerindeki etkilerinin incelendiği çalışmalarda en fazla programlama öğretimi (f:7), eğitsel robotik set kullanımı (f:4) ve blok tabanlı programlama (f:4) temalarının ele alındığı görülmektedir. Çeşitli değişkenler ile BİD becerisi arasındaki ilişkinin incelendiği çalışmalarda en fazla akademik başarı (f:2) teması ele alınmıştır. BİD becerisinin geliştirilmesine yönelik tasarım ve geliştirme çalışmalarında ise en fazla etkinlik (f:2) tasarımının gerçekleştirildiği çalışmalar yer almaktadır. Lisansüstü tezlerin bilim dallarına göre dağılımları Tablo 2'de verilmiştir.

Tablo 2

Lisansüstü Tezlerin Bilim Dallarına Göre Dağılımı

\begin{tabular}{|c|c|c|c|}
\hline Bilim Dalları & Yüksek Lisans & Doktora & $\mathrm{f}$ \\
\hline $\begin{array}{l}\text { - } \text { Bilgisayar } \\
\text { mühendisliği }\end{array}$ & Y21 & & 1 \\
\hline $\begin{array}{l}\text { - Bilgisayar ve } \\
\text { öğretim } \\
\text { teknolojileri eğitimi }\end{array}$ & $\begin{array}{l}\text { Y1, Y3, Y4, Y5, Y6, Y9, Y11, Y13, Y14, Y15, } \\
\text { Y16, Y17, Y20, Y22, Y23, Y24, Y25, Y27, } \\
\text { Y28, Y29, Y30 }\end{array}$ & $\begin{array}{l}\text { D1, D2, } \\
\text { D3, D8 }\end{array}$ & 25 \\
\hline - Eğitim bilimleri & Y7, Y18 & $\begin{array}{l}\text { D4, D6, } \\
\text { D7 }\end{array}$ & 5 \\
\hline - Eğitim teknolojileri & Y12, Y19 & & 2 \\
\hline - Enformatik & Y26 & D5 & 2 \\
\hline - Fen bilgisi eğitimi & $\mathrm{Y} 1, \mathrm{Y} 10$ & & 2 \\
\hline $\begin{array}{l}\text { İnternet ve bilişim } \\
\text { teknolojileri } \\
\text { yönetimi }\end{array}$ & Y8 & & 1 \\
\hline
\end{tabular}

Toplam

Tablo 2'de görüldüğü üzere bilgi işlemsel düşünme becerisine yönelik lisansüstü tezlerin çoğunlukla Bilgisayar ve Öğretim Teknolojileri Eğitimi (f:25) alanında yapıldığı görülmektedir. Bu durumu sırasıyla Eğitim Bilimleri (f:5), Eğitim Teknolojileri (f:2), Enformatik (f:2), Fen Bilgisi (f:2), Bilgisayar Mühendisliği (f:1), İnternet ve Bilişim Teknolojileri Yönetimi (f:1) bilim dalları takip etmektedir. Lisansüstü tezlerin yayınlandığı yıllara göre dağılımları Tablo 3'te verilmiştir. 
Tablo 3

Lisansüstü Tezlerin Yıllara Göre Dağılımı

\begin{tabular}{|c|c|c|c|}
\hline Yillar & Yüksek lisans & Doktora & $\mathrm{f}$ \\
\hline - 2016 & & D8 & 1 \\
\hline - 2017 & Y1, Y2, Y30 & & 3 \\
\hline - $\quad 2018$ & Y3, Y4, Y5, Y6, Y7 & D1, D2, D3 & 8 \\
\hline - 2019 & $\begin{array}{l}\text { Y8, Y9, Y10, Y11, Y12, Y13, Y14, Y15, Y16, Y17, Y18, } \\
\text { Y19, Y20, Y21, Y22, Y23, Y24, Y25, Y26, Y27, Y28, } \\
\text { Y29 }\end{array}$ & D4, D5, D7 & 25 \\
\hline - 2020 & & D6 & 1 \\
\hline Toplam & & & 38 \\
\hline
\end{tabular}

Tablo 3’teki bilgi işlemsel düşünme becerisine yönelik lisansüstü tezlerin yıllara göre dağılımı incelendiğinde ilk çalışmanın 2016 yılında yayınlandığı görülmektedir. En fazla çalışmanın ise 2019 (f:25) yılında yayınlandığı görülmektedir. Bununla birlikte bu çalışmada kullanılan veriler Nisan 2020 tarihine kadar yayınlanmış lisansüstü tezlerle sınırlıdır. Dolayısıyla ilerleyen zamanlarda 2020 yılı içeresinde yayınlanan lisansüstü tezlerin sayısında artışlar yaşanabilir. Bu istisna durum göz önünde bulundurulduğunda bilgi işlemsel düşünme becerisine yönelik lisansüstü tezlerin sayısında yıllara (20162019) göre artış yaşandığı görülmektedir.

Türkiye'de bilgi işlemsel düşünme becerisine yönelik yapılmış lisansüstü tezlerin metodolojik açıdan genel özellikleri

$\mathrm{Bu}$ bölümde lisansüstü tezlerde kullanılan araştırma yöntemleri, araştırma modelleri, örneklem profili, veri toplama araçları ve veri analiz teknikleri hakkında bilgiler sunulmuştur. Lisansüstü tezlerde kullanılan araştırma yöntemlerine ilişkin bilgiler Tablo 4'te verilmiştir.

Tablo 4

Lisansüstü Tezlerde Kullanılan Araştırma Yöntemleri

\begin{tabular}{llll}
\hline Yöntem & Yüksek lisans & Doktora & $\mathrm{f}$ \\
\hline$\bullet \quad$ Nicel & Y1, Y2, Y5, Y6, Y7, Y9, Y10, Y12, Y13, Y14, & 20 \\
& Y15, Y16, Y17, Y18, Y19, Y21, Y22, Y23, & \\
& Y26, Y28 & & 7 \\
- Nitel & Y8, Y11, Y24, Y27, Y29 & D2, D8 & 11 \\
• Karma & Y3, Y4, Y20, Y25, Y30 & D1, D3, D4, D5, D6, D7 & 11 \\
\hline Toplam & & & 38 \\
\hline
\end{tabular}


Tablo 4 incelendiğinde lisansüstü tezlerde en çok nicel araştırma yöntemi (f: 20) kullanılmasına karşın sadece nicel yöntem kullanılarak yayınlanan doktora tezi bulunmamaktadır. Doktora tezlerinin büyük çoğunluğunda karma araştırma yönteminin (f:6) kullanıldığı görülmektedir. Bununla birlikte lisansüstü tezlerde en az nitel araştırma yöntemi kullanılmıştır. Lisansüstü testlerde kullanılan araştırma desenleri/modelleri Tablo 5'te verilmiştir.

Tablo 5

Lisansüstü Tezlerde Kullanılan Araştırma Desenleri/Modelleri

\begin{tabular}{|c|c|c|c|}
\hline Desen/Model & Yüksek lisans & Doktora & $\mathrm{f}$ \\
\hline - Açıklayıcı sıralı desen & Y3 & & 1 \\
\hline - Durum çalışması & Y11, Y24, Y25, Y27, Y29 & D8 & 6 \\
\hline - Betimsel tarama & Y2, Y7, Y22 & & 3 \\
\hline - İlişkisel tarama & Y18 & & 1 \\
\hline - Deneysel & Y10, Y12, Y28 & & 3 \\
\hline - Geliştirme araştırması & & D2 & 1 \\
\hline - Gömülü deneysel desen & Y4 & D7 & 2 \\
\hline - Keşfedici ardışık desen & & D6 & 1 \\
\hline - Yarı deneysel desen & $\begin{array}{l}\text { Y1, Y5, Y6, Y9, Y13, Y14, } \\
\text { Y15, Y16, Y17, Y19, Y23, } \\
\text { Y26, Y30 }\end{array}$ & D1, D5 & 15 \\
\hline $\begin{array}{l}\text { - Tasarım tabanlı } \\
\text { araştırma }\end{array}$ & Y20 & D4 & 2 \\
\hline $\begin{array}{l}\text { - Tasarım ve geliştirme } \\
\text { araştırması }\end{array}$ & Y8 & & 1 \\
\hline - Yakınsayan paralel desen & & D3 & 1 \\
\hline - Belirtilmemiş & Y21 & & 1 \\
\hline Toplam & & & 38 \\
\hline
\end{tabular}

Tablo 5'te görüldüğü üzere lisansüstü tezlerde en çok kullanılan araştırma deseninin yarı deneysel desen (f:15) olduğu görülmektedir. Bu sırayı durum çalışması ( f: 6), betimsel tarama (f:3) ve deneysel araştırma modeli (f:3) takip etmektedir. En az kullanılan araştırma modelinin/desenin ise açıllayıcı sıralı desen (f:1), ilişkisel tarama (f:1), geliştirme araştırması (f:1), keşfedici ardışık desen (f:1), tasarım ve geliştirme araştırması (f:1), yakınsayan paralel desen (f:1) olduğu görülmektedir. Ayrıca bir çalışmada da hangi 
desene göre tasarlandığı belirtilmemiştir. Lisansüstü tezlerin örneklem profili Tablo 6’da verilmiștir.

Tablo 6

Lisansüstü Tezlerin Örneklem Profili

\begin{tabular}{llll}
\hline Örneklem Profili & Yüksek lisans & Doktora & $\mathrm{f}$ \\
\hline - & Okul öncesi & D8 & 1 \\
- & İlkokul & Y2*, Y8 & 2 \\
- Ortaokul & Y1, Y2, Y4, Y5, Y9, Y10, Y11, Y12, Y13, Y14, D1, D2*, & 26 \\
& Y16, Y18, Y19, Y22, Y23, Y25, Y26, Y27, D3, D5, D6, \\
& Y28, Y30 & D7 & \\
- Lise & Y2, Y15, Y17*, Y20* & & 4 \\
- Üniversite & Y6, Y7 & D4 & 3 \\
- Öğretmen & Y17, Y20, Y24, Y29 & & 4 \\
- Akademisyen & & D2 & 1 \\
\hline Toplam & & & 41 \\
\hline
\end{tabular}

*Birden fazla katılımcı profili olan çalışmalar.

Tablo 6 incelendiğinde lisansüstü tezlerde en çok ortaokul (f:26) örneklem profili ile çalışıldığı görülmektedir. Bu sırayı lise (f:4), öğretmen (f:4) ve üniversite (f:3) katılımcı profili takip etmektedir. En az çalışılan örneklem profili ise okul öncesi (f:1) ve akademisyen (f:1) profilinden oluşmaktadır. Ayrıca Bilgisayar Mühendisliği bilim dalında gerçekleştirilen Y21 kodlu çalışmada örneklem profili olarak veri setleri kullanıldığından tabloya dâhil edilmemiştir. Lisansüstü tezlerde kullanılan veri toplama araçları Tablo 7'de verilmiştir.

Tablo 7

Lisansüstü Tezlerde Kullanılan Veri Toplama Araçları

\begin{tabular}{llll}
\hline Veri Toplama Aracl & Yüksek lisans & Doktora & f \\
\hline - Anket & Y29 & D2* & 2 \\
- Ölçek & Y1, Y2, Y3*, Y4*, Y5, Y6, Y7, Y9, & D1*, & D3*, 28 \\
& Y10, Y12, Y13, Y14, Y15, Y16, Y17, & D5 $^{*}$, D6*, D7* & \\
& Y18, Y19, Y22, Y23, Y25*, Y26, & & \\
& Y28, Y30* & & \\
- Rubrik & Y20* & D2, D4, D7 & 4 \\
\hline
\end{tabular}


- Envanter

- Dereceli puanlama anahtarı

- Değerlendirme formu

- Gözlem

- Günlük

- Klinik görüşme

- Mülakat

- Görüşme

\section{Y30}

D3, D6, D7

D4

D2

D1

Y11, Y27

Y3, Y4, Y8, Y20, Y24, Y25, Y29,

Y30
D6

D8

1

1

1

D2, D4, D5, D6, 14

D7, D8

\section{Toplam}

* Birden fazla veri toplama aracının kullanıldığı çalışmalar.

Tablo 7'de görüldüğü üzere lisansüstü tezlerde en çok kullanılan veri toplama araçlarının sırasıyla ölçek (f:28), görüşme (f:14), gözlem (f:5) ve rubrik (f:4) olduğu görülmektedir. En az kullanılan veri toplama araçları ise envanter (f:1), dereceli puanlama anahtarı (f:1), değerlendirme formu (f:1) ve klinik görüşme (f:1) veri toplama araçlarıdır. Ayrıca Y21 kodlu çalışmada hangi veri toplama aracının kullanıldığı belirtilmediği için tabloya dahil edilmemiştir. Lisansüstü tezlerde kullanılan veri analiz teknikleri Tablo 8'de verilmiştir.

Tablo 8

Lisansüstü Tezlerde Kullanılan Veri Analiz Teknikleri

\begin{tabular}{|c|c|c|c|c|}
\hline \multicolumn{2}{|c|}{ Veri analiz tekniği } & Yüksek lisans & Doktora & \multirow{2}{*}{$\begin{array}{l}\mathrm{f} \\
15\end{array}$} \\
\hline Betimsel & $\begin{array}{l}\text { Frekans, } \\
\text { yüzde, } \\
\text { ortalama, } \\
\text { standart } \\
\text { sapmama vb. }\end{array}$ & $\begin{array}{l}\text { Y2, Y4, Y18*, Y20*, Y23*, } \\
\text { Y25*, Y28*, Y29*, Y30* }\end{array}$ & $\begin{array}{l}\mathrm{D} 2^{*}, \mathrm{D} 3^{*}, \quad \mathrm{D} 4^{*}, \\
\mathrm{D}^{*}, \mathrm{D} 7^{*}, \mathrm{D}^{*}\end{array}$ & \\
\hline \multirow[t]{4}{*}{ Kestirimsel } & - T-Testi & $\begin{array}{l}\text { Y1, Y3, Y7*, Y9, Y10, Y14, } \\
\text { Y16*, Y17*, Y18, Y25, Y28, } \\
\text { Y30 }\end{array}$ & D5*, D7 & 14 \\
\hline & - Ancova & & D3, D6 & 2 \\
\hline & - Anova & $\mathrm{Y7}^{*}, \mathrm{Y} 9, \mathrm{Y} 16,{ }^{*} \mathrm{Y} 18, \mathrm{Y} 19$ & D3, D7 & 7 \\
\hline & - Mancova & & D6 & 1 \\
\hline
\end{tabular}




\begin{tabular}{|c|c|c|c|c|}
\hline & - Manova & Y5 & & 1 \\
\hline & $\begin{array}{l}\text { - Mann- Withney } \\
\text { U }\end{array}$ & Y13*, Y16, & D1*, D5 & 4 \\
\hline & $\begin{array}{l}\text { - } \quad \text { Kruskal-Wallis } \\
\mathrm{H}\end{array}$ & Y16, Y23 & & 2 \\
\hline & - Wilcoxon & Y6, Y12, Y13, Y15, Y23, Y26 & D1, D5 & 8 \\
\hline & - Korelasyon & Y7, Y18, Y22 & D8 & 4 \\
\hline Nitel & - İçerik analizi & $\begin{array}{l}\text { Y3, Y8, Y11, Y20, Y24, Y27, } \\
\text { Y29, Y30 }\end{array}$ & $\begin{array}{l}\text { D1, D2, D4, D5, } \\
\text { D6, D7, D8 }\end{array}$ & 15 \\
\hline
\end{tabular}

Toplam

* Birden fazla analiz tekniğinin kullanıldı̆̆ çalışmalar.

Tablo 8 incelendiğinde lisansüstü tezlerde en çok kullanılan veri analiz tekniklerinin sırasıyla kestirimsel (f:43), betimsel (f:15) ve içerik analizi (f:15) olduğu görülmektedir. Kestirimsel analiz teknikleri içerisinde en fazla T-testi (f:14) kullanılmıştır. En az ise Mancova (f:1), Manova (f:1), Ancova (f:2) ve Kruskal-Wallis H (f:2) testlerinin kullanıldığı görülmektedir.

\section{SONUÇ, TARTIŞMA VE ÖNERÍLER}

Bu çalışmada, Türkiye'deki bilgi işlemsel düşünme becerisine yönelik yapılmış lisansüstü tezler incelenmiştir. Bu kapsamda YÖK Ulusal Tez Merkezi veri tabanında kayıtlı 38 lisansüstü tez analiz edilmiştir. Analiz sonuçlarına göre lisansüstü tezlerde çoğunlukla programlama öğretimin, eğitsel robotik set kullanımının ve blok tabanlı görsel programlamanın bilgi işlemsel düşünme becerisi üzerindeki etkilerinin incelendiği çalışmalara rastlanmıştır. Bu sonuç Kalelioğlu (2018) tarafından yapılan araştırma sonucuyla paralellik göstermektedir. Bu durum, programlama öğretimine verilen önemin arttığını ve programlama öğretiminin bilgi işlemsel düşünme becerisi üzerindeki etkilerinin incelenmesinin araştırmacılar için önemli bir çalışma konusu olduğu şeklinde yorumlanabilir. Nitekim alanyazın incelendiğinde, programlama öğretiminin bilgi işlemsel düşünme becerisi üzerindeki etkilerinin incelendiği çok sayıda arştırmaya ulaşmak mümkündür (Atmatzidou ve Demetriadis, 2018; Djambong ve Freiman, 2016; Nouri, Zhang, Mannila ve Noren, 2019; Pérez-Marín, Hijón-Neira, Bacelo ve Pizarro, 2020; Portelance ve Bers, 2015).

Bununla birlikte ortaya çlkan bir diğer sonuç ise bilgi işlemsel düşünme becerisinin geliştirilmesine yönelik, odak noktası etkinlik, öğrenme ortamı veya program tasarımı olan tezlerin sayısının ise oldukça az olduğudur. Oysaki bilgi işlemsel düşünme becerisinin geliştirilmesi sürecinde etkinlik, öğrenme ortamı veya program tasarımının önemli roller üstlendiği bilinmektedir (Wing, 2008). Dolayısıyla bilgi işlemsel düşünme 
becerisinin geliştirilmesine yönelik yapılmış tasarım çalışması sayısının az olması, bu alanda bir boşluğun olduğuna işaret etmektedir. $\mathrm{Bu}$ durum, bilgi işlemsel düşünme becerisi ile ilgili tez hazırlayan araştırmacıların dikkatini yeterince çekmemiş olabileceği şeklinde yorumlanabilir.

Bilgi işlemsel düşünme becerisiyle ilgili tezlerin bilim dallarına göre dağılımı incelendiğinde büyük çoğunluğunun Bilgisayar ve Öğretim Teknolojileri Eğitimi alanında yapıldığı görülmektedir. Bilgi işlemsel düşünme becerisi kavramının en yalın haliyle "teknolojiyi kullanarak problem çözmek" olarak ifade edilmesi (Gretter ve Yadav, 2016) ve bilgi işlemsel düşünme becerisine yönelik çalışmalarda ağırlıklı olarak bilgisayar bilimleri ile programlama içeriklerinin kullanılıyor olmasının (Bers, Flannery, Kazakoff ve Sullivan, 2014; Caldwell ve Smith, 2016) bu durum üzerinde etkili olabileceği söylenebilir. Eğitim Bilimleri, Eğitim Teknolojileri, Enformatik, Fen Bilgisi Eğitimi, İnternet ve Bilişim Teknolojileri Yönetimi ve Bilgisayar Mühendisliği bilim dallarında ise çok az sayıda çalışmanın yapıldığı görülmektedir. Benzer çalışma sayılarının bu bilim dallarında da yapılmasının bilgi işlemsel düşünme becerisinin geliştirilmesinde önemli katkılar sağlayacağı düşünülmektedir.

Bilgi işlemsel düşünme becerisi ile ilgili yapılan lisansüstü tezlerin sayısı oldukça sınırlıdır. Lisansüstü tezlerin 2016 yılından itibaren görünmeye başlandığı ve tezlerin büyük çoğunluğunun 2019 yılında yayınlandığı görülmektedir. Bilgi işlemsel düşünme becerisi nispeten yeni sayılabilecek bir çalışma alanıdır, lisansüstü bir tez çalışmasının en az iki yıllık bir süreçten sonra yayınlanabildiği düşünüldüğünde ilk çalışmaların aslında 2016 yılından önce başladığı söylenebilir. Bununla birlikte bu çalışmada kullanılan veriler Nisan 2020 tarihine kadar yayınlanmış lisansüstü tezlerle sınırlıdır. Dolayısıyla ilerleyen zamanlarda 2020 yılı içeresinde yayınlanan lisansüstü tezlerin sayısında artışlar yaşanabilir. Bu istisna durum göz önünde bulundurulduğunda bilgi işlemsel düşünme becerisine yönelik lisansüstü tezlerin sayısında yıllara (2016-2019) göre artış yaşandığı söylenebilir. Bu sonuç Haseski, Ilic ve Tugtekin, (2018), Tang, Chou ve Tsai (2020) tarafından yapılan araştırma sonuçlarıyla örtüşmektedir. Benzer şekilde Tang ve arkadaşları (2020) tarafından bilgi işlemsel düşünme becerisine yönelik 2006 ile 2018 yıları arasında yapılan araştırmalar incelendiğinde bilgi işlemsel düşünme becerisine yönelik araştırma sayısında 2013 ile 2018 yılları arasında büyük artışların yaşandığı sonucuna ulaşılmıştır.

Lisansüstü tezler yöntemsel olarak incelendiğinde, çalışmaların büyük çoğunluğunun nicel araştırma yöntemle yarı deneysel desen kullanılarak tasarlandığı sonucuna ulaşılmıştır. Bu durumun tezlerin konusu, amacı ve tezlerde kullanılan veri toplama araçlarıyla ilgili olduğu düşünülmektedir. Bu bağlamda lisansüstü tezlerin büyük çoğunluğunun farklı değişkenlerin bilgi işlemsel düşünme becerisi üzerindeki etkilerini belirlemeyi amaçladığı için nicel araştırma yönteminin daha çok tercih edilmiş olabileceği söylenebilir. Lisansüstü tezlerde veri toplama aracı olarak çoğunlukla ölçek kullanımının tercih edilmesine bağlı olarak nicel yöntem ve yarı deneysel desenin daha çok tercih edilmiş olabileceği düşünülmektedir. Başka bir ifadeyle araştırmanın yönteminin 
araştırmanın amacına göre değişebileceği söylenebilir. Ayrıca, lisansüstü tezlerde nicel araştırma yöntemlerinin daha çok tercih edilmesinde, araştırmaya seçilen tezlerin ağırlıklı olarak yüksek lisans tezi olmasından kaynaklanmış olabileceği düşünülmektedir. Yine nicel araştırma yöntemlerinde veri toplama ve uygulama süreçlerinin nitel araştırmalara göre daha kısa sürmesi de etkin bir rol oynamış olabilir. Araştırmanın bu sonucu Kalelioglu, Gulbahar ve Kukul (2016) tarafından yapılan araştırma sonuçlarıyla desteklenmektedir. Kalelioğlu ve arkadaşları (2016) araştırmalarında bilgi işlemsel düşünme becerisine yönelik 125 araştırma incelemiştir. Makalelerin türlerine ve araştırma yöntemine göre yaptıkları analiz sonucunda nicel araştırma yöntemlerinin (f:33) diğer yöntemlerden (f:31) daha çok kullanıldığı tespit edilmiştir.

Bilgi işlemsel düşünme becerisi ile ilgili tezler örneklem profili açısından incelendiğinde, lisansüstü tezlerde en çok ortaokul düzeyinin tercih edildiği görülmüştür. Bunu sırasıyla lise ve üniversite düzeyleri takip etmektedir. Araştırmanın bu sonucu De Araujo, Andrade ve Guerrero (2016); İlic ve Haseski (2019); Tang, Chou ve Tsai (2020) tarafından yapılan araştırma sonuçlarıyla paralellik göstermektedir. Lisansüstü tezlerde, çoğunlukla bilgi işlemsel düşünme becerisinin öğrenci boyutuyla incelenmiş olmasının, lisansüstü tezlerde daha çok ortaokul öğrencilerinin tercih edilmesinde etkili olmuş olabilir. Bununla birlikte akademisyen ve okul öncesi örneklem gruplarıyla çok az sayıda çalışıldığı görülmektedir. Oysaki 21.yy becerisi olarak nitelendirilen bilgi işlemsel düşünme becerisinin kazandırılması, bütün yaş gruplarında ve öğrenim düzeylerinde, üzerinde durulması gereken önemli bir konu olarak değerlendirilmektedir (Wing, 2008).

Lisansüstü tezlerde ağırlıklı olarak ölçek, görüşme ve gözlem veri toplama araçları kullanılmıştır. Benzer şekilde De Araujo, Andrade ve Guerrero (2016); Weinberg (2013) tarafından yapılan araştırmalarda bilgi işlemsel düşünme becerisine yönelik çoğunlukla test, anket ve görüşme gibi veri toplama araçlarının kullanıldığı tespit edilmiştir. Toplanan verilerin analizinde sırasıyla en çok kestirimsel, betimsel ve içerik analizi tekniklerinin kullanıldığı görülmüştür. Kestirimsel analizlerde en fazla t-testi kullanılırken nitel analizlerde ise içerik analizi kullanılmıştır. Lisansüstü tezlerde çoğunlukla t-testinin kullanılmasında ağırlıklı olarak nicel araştırma desenlerinden yarı deneysel desen kullanılmasının etkili olmuş olabileceği düşünülmektedir.

Araştırma sonucunda, bilgi işlemsel düşünme becerisi ile ilgili lisansüstü tezlerde farklı değişkenlerin bilgi işlemsel düşünme becerisi üzerindeki etkisinin incelendiği araştırmalara daha sık rastlanmaktadır. Diğer taraftan bilgi işlemsel düşünme becerisinin geliştirilmesine yönelik öğrenme ortamı, öğretim tasarımı, program tasarımı veya etkinlik tasarımlarının yapıldığı lisansüstü tezlerin sayısının oldukça az olduğu görülmektedir. Bu bağlamda bilgi işlemsel düşünme becerisinin desteklenmesine yönelik etkinlik, uygulama veya öğrenme ortamı tasarımlarının yapıldı̆̆ı araştırmaların yapılması alana önemli katkılar sağlayabilir. Lisansüstü tezlerde daha çok nicel araştırma yönteminin tercih edildiği görülmektedir. Bu kapsamda nitel veya karma araştırma yöntemlerinin kullanıldığı araştırmaların yapılması önerilebilir. Lisansüstü tezlerde okul öncesi örneklem gruplarıyla yapılmış çok az sayıda çalışmanın olduğu görülmektedir. $\mathrm{Bu}$ 
bağlamda bilgi işlemsel düşünme becerisi ile ilgili yapılacak lisansüstü tezlerde okul öncesi örneklem gruplarının tercih edilmesinin alanyazına önemli katkılar sağlayacağı düşünülmektedir.

\section{Kaynaklar}

Atmatzidou, S., Demetriadis, S. ve Nika, P. (2018). How does the degree of guidance support students' metacognitive and problem solving skills in educational robotics. Journal of Science Education and Technology, 27(1), 70-85.

Bers, M. U. (2010). The tangiblek robotics program: Applied computational thinking for young children. Early Childhood Research \& Practice, 12(2), 1-20.

Bers, M. U., Flannery, L., Kazakoff, E. R. ve Sullivan, A. (2014). Computational thinking and tinkering: Exploration of an early childhood robotics curriculum. Computers \& Education, 72, 145-157.

Büyüköztürk, Ş., Çakmak, E. K., Akgün, Ö. E., Karadeniz, Ș. ve Demirel, F. (2008). Bilimsel araştırma yöntemleri. Pegem Akademi, Ankara.

Caldwell, H. ve Smith, N. (2016). Teaching computing unplugged in primary schools: exploring primary computing through practical activities away from the computer. Sage Publication, London.

Care, E., Scoular, C. ve Griffin, P. (2016). Assessment of collaborative problem solving in education environments. Applied Measurement in Education, 29(4), 250-264.

Center for Computational Thinking Carnegie Mellon (2020). What is computational thinking? https://www.cs.cmu.edu/ CompThink/ adresinden erişilmiştir.

Çalık, M. ve Sözbilir, M. (2014). İçerik analizinin parametreleri. Eğitim ve Bilim, 39(174), 33-38.

Çınar, M. ve Tüzün, H. (2017). Eğitimde bilgisayımsal düşünme uygulamalarına ilişkin bir alanyazın incelemesi. Uluslararası Bilgisayar ve Öğretim Teknolojileri Eğitimi Sempozyumunda sunulan bildiri. İnöünü Üniversitesi, Malatya, Türkiye.

De Araujo, A. L. S. O., Andrade, W. L. ve Guerrero, D. D. S. (2016, October). A systematic mapping study on assessing computational thinking abilities. Proceeding of the IEEE Frontiers in Education Conference, USA. https://ieeexplore.ieee.org/abstract/document/7757678 adresinden erişilmiştir.

Demirer, V. ve Sak, N. (2016). Dünyada ve Türkiye'de programlama eğitimi ve yeni yaklaşımlar. Eğitimde Kuram ve Uygulama, 12(3), 521-546.

Djambong, T. ve Freiman, V. (2016, October). Task-based assessment of students' computational thinking skills developed through visual programming or tangible coding environments. Proceeding of the Cognition and Exploratory Learning in the Digital Age Conference, Mannheim, Germany. https://files.eric.ed.gov/fulltext/ED571389.pdf adresinden erişilmiştir.

Gonzalez, M. R. (2015, July). Computational thinking test: Design guidelines and content validation. Proceeding of the 7th International Conference on Education and New Learning Technologies, Barcelona, Spain. https://library.iated.org/view/ROMANGONZALEZ2015COM adresinden erişilmiştir.

Gretter, S. ve Yadav, A. (2016). Computational thinking and media \& information literacy: An integrated approach to teaching twenty-first century skills. TechTrends, 60(5), 510-516. 
Griffin, P. (2017). Innovative assessment of collaboration. Springer, Cham

Grover, S. ve Pea, R. (2013). Computational thinking in K-12: A review of the state of the field. Educational Researcher, 42, 38-43.

Gülbahar, Y. ve Kalelioğlu, F. (2018). Bilişim teknolojileri ve bilgisayar bilimi: Öğretim programı güncelleme süreci. Millî Eğitim Dergisi, 47(217), 5-23.

Haseski, H. İ., Ilic, U. ve Tugtekin, U. (2018). Defining a new 21st century skill-computational thinking: concepts and trends. International Education Studies, 11(4), 29-42.

Ilic, U., Haseski, H. İ. ve Tugtekin, U. (2018). Publication trends over 10 years of computational thinking research. Contemporary Educational Technology, 9(2), 131-153.

Israel, M., Pearson, J. N., Tapia, T., Wherfel, Q. M. ve Reese, G. (2015). Supporting all learners in school-wide computational thinking: A cross-case qualitative analysis. Computers \& Education, 82, 263-279.

ISTE ve CSTA. (2011). Operational definition of computational thinking for K-12 education. https://id.iste.org/docs/ct-documents/computational-thinking-operational-definitionflyer.pdf?sfvrsn=2 adresinden erişilmiştir.

International Society for Technology in Education (2015). Computational thinking for all. https://www.iste.org/explore/Solutions/Computational-thinking-for-all adresinden erişilmiştir.

İlic, U. ve Haseski, H. İ. (2019, Kasım). Bilgi işlemsel düşünmeyi ölçmeye yönelik geliştirilen veri toplama araçlarının incelenmesi [Öz]. I. Uluslararası Bilim Eğitim Sanat ve Teknoloji Sempozyumunda sunulan bildiri, Dokuz Eylül Üniversitesi, İzmir. http://ubest.deu.edu.tr/BEST2018/tam-metin-bildiri-kitabi adresinden erişilmiştir.

Kaan, B. A. T. I., Çalışkan, İ. ve Yetişir, M. İ. (2017). Fen eğitiminde bilgi işlemsel düşünme ve bütünleştirilmiş alanlar yaklaşımı (STEAM). Pamukkale Üniversitesi Eğitim Fakültesi Dergisi, 41(41), 91-103.

Kalelioğlu F. (2018). Characteristics of studies conducted on computational thinking: a content analysis. In: Khine M. (eds) Computational thinking in the stem disciplines, 11-99. Springer, Cham

Kalelioğlu, F., Gülbahar, Y. ve Kukul, V. (2016). A framework for computational thinking based on a systematic research review. Baltic J. Modern Computing, 4 (3), 583-596.

Karasar, N. (2016). Bilimsel araştırma yöntemi. Nobel Akademik Yayıncılık, Ankara.

Korkmaz, Ö., Cakir, R. ve Özden, M. Y. (2017). A validity and reliability study of the computational thinking scales (CTS). Computers in Human Behavior, 72, 558-569.

Lee, I., Martin, F., Denner, J., Coulter, B., Allan, W., Erickson, J. ve Werner, L. (2011). Computational thinking for youth in practice. Acm Inroads, 2(1), 32-37.

Magana, A. J. ve Silva Coutinho, G. (2017). Modeling and simulation practices for a computational thinking-enabled engineering workforce.Computer Applications in Engineering Education, 25(1), 62-78.

Mannila, L., Dagiene, V., Demo, B., Grgurina, N., Mirolo, C., Rolandsson, L. ve Settle, A. (2014). Computational thinking in K-9 education. In A. Clear and R. Lister (Eds.),Proceedings of the working group reports of the 2014 on innovation \& technology incomputer science education conference, 1-29. ACM. 
Milles, M. B. ve Huberman, A. M. (1994). An expanded sourcebook: Qualitative data analysis. Sage, London.

Nouri, J., Zhang, L., Mannila, L. ve Norén, E. (2020). Development of computational thinking, digital competence and 21st century skills when learning programming in K-9. Education Inquiry, 11(1), 1-17.

Oluk, A., Korkmaz, Ö. ve Oluk, H. A. (2018). Scratch'ın 5. sınıf öğrencilerinin algoritma geliştirme ve bilgi-işlemsel düşünme becerilerine etkisi. Turkish Journal of Computer and Mathematics Education, 9(1), 54-71.

Özçinar, H. (2017). Hesaplamalı düşünme araştırmalarının bibliyometrik analizi. Eğitim Teknolojisi Kuram ve Uygulama, 7(2), 149-171.

Özkeş, B. (2016). Bilişimsel düşünme temelli ders etkinliklerinin öğrencilerin eleștirel düşünme becerileri ve problem çözme becerilerine yönelik algıları üzerine etkisinin incelenmesi. (Yayımlanmamış yüksek lisans tezi). Mevlana üniversitesi, Konya.

Pérez-Marín, D., Hijón-Neira, R., Bacelo, A. ve Pizarro, C. (2020). Can computational thinking be improved by using a methodology based on metaphors and scratch to teach computer programming to children? Computers in Human Behavior, 105, 84-99.

Portelance, D. J. ve Bers, M. U. (2015, June). Code and Tell: Assessing young children's learning of computational thinking using peer video interviews with ScratchJr. In Proceedings of the 14th international conference on interaction design and children, Medford, USA. https://dl.acm.org/doi/pdf/10.1145/2771839.2771894 adresinden erişilmiştir.

Riley, D. D. ve Hunt, K. A. (2014). Computational thinking for the modern problem solver. Boca Raton, FL: CRC Press.

Snalune, P. (2015). The benefits of computational thinking. ITNOW, 57(4), 58-59.

Şahiner, A. ve Kert, S. B. (2016). Examining studies related with the concept of computational thinking between the years of 2006-2015. European Journal of Science and Technology, 5(9), 38-43.

Şimşek, N. ve Yaşar, A. (2019). GeoGebra ile ilgili lisansüstü tezlerin tematik ve yöntemsel eğilimleri: Bir içerik analizi. Turkish Journal of Computer and Mathematics Education, 10(2), 290-313.

Tang, K. Y., Chou, T. L. ve Tsai, C. C. (2020). A content analysis of computational thinking research: An international publication trends and research typology. The Asia-Pacific Education Researcher, 29(1), 9-19.

Tosik-Gün, E. ve Güyer, T. (2019). Bilgi işlemsel düşünme becerisinin değerlendirilmesine ilişkin sistematik alanyazın taraması. Ahmet Keleşoğlu Eğitim Fakültesi Dergisi, 1(2), 99-120.

Üzümcü, Ö. ve Bay, E. (2018). Eğitimde yeni 21. yüzyıl becerisi: Bilgi işlemsel düşünme. Uluslararası Türk Kültür Coğrafyasında Sosyal Bilimler Dergisi, 3(2), 1-16.

Weinberg, A. E. (2013). Computational thinking: An investigation of the existing scholarship and research. Unpublished Doctoral Dissertation, Colorado State University, Colorado, USA.

Wing, J. M. (2008). Computational thinking and thinking about computing. Philosophical Transactions of the Royal Society A: Mathematical, Physical and Engineering Sciences, 366(1881), 3717-3725. 
Wong, K. W. G., Chıng, C. C., Mark, K. P., Tang, J. K., Lei, C. U., Cheung, H. Y. ve Chuı, H. L. (2015). Impact of computational thinking through coding in K-12 education: A pilot study in Hong Kong. General Studies, 85(88), 2-8. 


\section{Ekler}

Ek. Bu çalışma kapsamında analiz edilen lisansüstü tezler ve kodları

\begin{tabular}{|c|c|}
\hline Kod & Lisansüstü tez \\
\hline Y1 & $\begin{array}{l}\text { Çakır, E. (2017). Ters yüz sınıf uygulamalarının fen bilimleri 7.sınıf öğrencilerinin akademik başarı, } \\
\text { zihinsel risk alma ve bilgisayarca düşünme becerileri üzerine etkisi (Yayınlanmamış yüksek lisans tezi). } \\
\text { Ondokuz Mayıs Üniversitesi, Eğitim Bilimleri Enstitüsü, Samsun. }\end{array}$ \\
\hline Y2 & $\begin{array}{l}\text { Oluk, A. (2017). Öğrencilerin bilgisayarca düşünme becerilerinin mantıksal matematiksel zeka ve } \\
\text { matematik akademik başarıları açısından incelenmesi (Yayınlanmamış yüksek lisans tezi). Amasya } \\
\text { Üniversitesi, Fen Bilimleri Enstitüsü, Amasya. }\end{array}$ \\
\hline Y3 & $\begin{array}{l}\text { Erdem, E. (2018). Blog tabanlı ortamlarda programlama öğretimi sürecinde farklı öğretim stratejilerinin } \\
\text { çeşitli değişkenler açısından incelenmesi (Yayınlanmamış yüksek lisans tezi). Başkent Üniversitesi, } \\
\text { Eğitim Bilimleri Enstitüsü, Ankara. }\end{array}$ \\
\hline Y4 & $\begin{array}{l}\text { Yolcu, V. (2018). Programlama eğitiminde robotik kullanımının akademik başarı, bilgi-işlemsel düşünme } \\
\text { becerisi ve öğrenme transferine etkisi (Yayınlanmamış yüksek lisans tezi). Süleyman Demirel } \\
\text { Üniversitesi, Eğitim Bilimleri Enstitüsü, Isparta. }\end{array}$ \\
\hline Y5 & $\begin{array}{l}\text { Şimşek, E. (2018). Programlama öğretiminde robotik ve scratch uygulamalarının öğrencilerin bilgi } \\
\text { işlemsel düşünme becerileri ve akademik başarılarına etkisi (Yayınlanmamış yüksek lisans tezi). } \\
\text { Ondokuz Mayıs Üniversitesi, Eğitim Bilimleri Enstitüsü, Samsun. }\end{array}$ \\
\hline Y6 & $\begin{array}{l}\text { Akkaya, A. (2018). Eğitsel oyunların öğrencilerin nesne tabanlı programlamanın temel kavramsal bilgisi } \\
\text { ve bilgi ișlemsel düşünme becerilerine etkisi (Yayınlanmamış yüksek lisans tezi). Boğaziçi Üniversitesi, } \\
\text { Sosyal Bilimleri Enstitüsü, İstanbul. }\end{array}$ \\
\hline
\end{tabular}

Y7 Çatana-Kuleli, S. (2018). Öğretmen adaylarının çevrimiçi öğrenmeye hazırbulunuşluk düzeyleri ve bilgi işlemsel düşünme becerilerinin değerlendirilmesi (Yayınlanmamış yüksek lisans tezi). Düzce Üniversitesi, Sosyal Bilimleri Enstitüsü, Düzce.

Y8 Özyol, B. (2019). Bilgi-İslemsel düşünme becerisinin kazandırılmasına yönelik bir ortam tasarımı ve geliştirilmesi (Yayınlanmamış yüksek lisans tezi). Afyon Kocatepe Üniversitesi, Fen Bilimleri Enstitüsü, Afyon Kocatepe.

Y9 Turan, B. (2019). Ortaokul öğrencilerinin geliştirdiği oyun ve robot projelerinde probleme dayalı öğrenmenin problem çözme ve bilgi işlemsel düşünme becerilerine etkisi (Yayınlanmamış yüksek lisans tezi). Van Yüzüncü Yıl Üniversitesi, Eğitim Bilimleri Enstitüsü, Van.

Y10 Çimentepe, E. (2019). Stem etkinliklerinin akademik başarı, bilimsel süreç becerileri ve bilgisayarca düşünme becerilerine etkisi (Yayınlanmamış yüksek lisans tezi). Niğde Ömer Halisdemir Üniversitesi, Eğitim Bilimleri Enstitüsü, Niğde.

Y11 Uğur, N. (2019).Bilgisayarsız ortamda bilgisayar bilimi öğretiminde yansıtıcı düşünme etkinliklerinin bilgi işlemsel düşünme becerileri geliştirmede etkisi (Yayınlanmamış yüksek lisans tezi). Trabzon Üniversitesi, Lisansüstü Eğitim Enstitüsü, Trabzon.

Y12 Uysal, Y. (2019). Blok tabanlı görsel programlamanın matematiksel problem çözme ve hesaplamalı düşünme üzerine etkileri (Yayınlanmamış yüksek lisans tezi). Boğaziçi Üniversitesi, sosyal Bilimler Enstitüsü, İstanbul.

Y13 Karaahmetoğlu, K. (2019).Proje tabanlı arduino eğitsel robot uygulamalarının öğrencilerin bilgisayarca düşünme becerileri ve temel stem beceri düzeyleri algılarına etkisi (Yayınlanmamış yüksek lisans tezi). Amasya Üniversitesi, Fen Bilimleri Enstitüsü, Amasya.

Y14 Çetinkaya, H. N. (2019).Bilişim teknolojileri ve yazılım dersindeki etkinliklerin bilgi işlemsel düşünme ve bazı değişkenler açısından incelenmesi (Yayınlanmamış yüksek lisans tezi). İnönü Üniversitesi, Eğitim Bilimleri Enstitüsü, Malatya.

Y15 Ergin, H. (2019).Programlama dersinde proje kullanımının öğrencilerin bilgi işlemsel düşünme becerilerine ve programlama öz yeterlilik inancına etkisi (Yayınlanmamış yüksek lisans tezi).Ege Üniversitesi, Fen Bilimleri Enstitüsü, İzmir.

Y16 Çelik-Kırçalı, A. (2019). K12 Düzeyinde algoritma öğretiminde kullanılan bilgisayarlı ve bilgisayarsız araçların çeşitli değişkenler açısından değerlendirilmesi (Yayınlanmamış yüksek lisans tezi).Marmara Üniversitesi, Eğitim Bilimleri Enstitüsü, İstanbul.

Y17 Huruzoğluı, N. (2019). Kısa süreli bir eğitimin öğrenci ve öğretmenlerin bilgi-işlemsel düşünme, programlama ve girişimcilik özyeterlik algıları üzerindeki etkisi (Yayınlanmamış yüksek lisans tezi).Orta Doğu Teknik Üniversitesi, Fen Bilimleri Enstitüsü, Ankara.

Y18 Paf, M. (2019). Ortaokul öğrencilerinin bilişimsel düşünme becerileri ile yaratıcı problem çözme becerileri arasındaki ilişki (Yayınlanmamış yüksek lisans tezi). Aydın Adnan Menderes Üniversitesi, Sosyal Bilimler Enstitüsü, Aydın.

Y19 Delal, H. (2019). Ortaokul öğrencilerinin bilgi işlemsel düşünme becerilerinin bilgisayarsız bilgisayar bilimi (b3) etkinlikleri ile geliştirilmesi (Yayınlanmamış yüksek lisans tezi). Boğaziçi Üniversitesi, Sosyla Bilimler Enstitüsü, İstanbul. 
Y20 Tutulmaz, M. (2019). Bilgi-işlemsel düşünme becerisinin geliştirilmesine yönelik veri görselleştirmenin tasarlanması, uygulanması ve değerlendirilmesi (Yayınlanmamış yüksek lisans tezi). Hacettepe Üniversitesi, Eğitim Bilimleri Enstitüsü, Ankara.

Y21 Karakaș, E. (2019). Bilgi ișlemsel düşünme becerilerinin makina öğrenmesi kullanarak performansa dayalı değerlendirilmesi (Yayınlanmamış yüksek lisans tezi). İstanbul Okan Üniversitesi, Fen Bilimleri Enstitüsü, İstanbul.

Y22 Kuleli, S. (2019). 8. Sinı öğrencilerinin bilgi işlemsel düşünme becerilerine yönelik özyeterlilik algılarının incelenmesi (Yayınlanmamış yüksek lisans tezi).Ege Üniversitesi, Eğitim Bilimleri Enstitüsü, İzmir.

Y23 Özel, O. (2019). Programlama yöntemlerinin ortaokul öğrencilerinin bilgi işlemsel düşünme becerisine yönelik öz yeterlik algısına ve programlama başarısına etkisi (Yayınlanmamış yüksek lisans tezi). Marmara Üniversitesi, Eğitim Bilimleri Enstitüsü, İstanbul.

Y24 Dağlı, Z. (2019). Bilişim teknolojileri öğretmenlerinin bilgisayar bilimi dersi "problem çözme ve algoritmalar" ünitesinde öğrencilerin bilgi-işlemsel düşünme becerilerini gelişstirmek için tasarladıkları öğretim tasarımı sürecinin incelenmesi (Yayınlanmamış yüksek lisans tezi). Mersin Üniversitesi, Eğitim Bilimleri Enstitüsü, Mersin.

Y25 Serim, E. (2019). Oyunlaștırma yöntemiyle tasarlanan kodlama eğitimi ile öğrencilerin hesaplamalı düşünme becerileri ve kodlamaya ilişkin öz-yeterlik algılarının incelenmesi (Yayınlanmamış yüksek lisans tezi). Balıkesir Üniversitesi, Fen Bilimleri Enstitüsü, Balıkesir.

Y26 Bal, N. (2019). Temel robotik eğitiminin ortaokul öğrencilerinin 21. yüzyıl becerilerine ve bilgi işlemsel düşünme becerilerine etkisi (Yayınlanmamış yüksek lisans tezi). Hatay Mustafa Kemal Üniversitesi, Fen Bilimleri Enstitüsü, Hatay.

Y27 Kocabıyık, N. (2019). Bilgisayarsız ortamda bilgisayar bilimi öğretiminde yansıtıcı düşünme etkinliklerinin bilgi işlemsel düşünme becerileri geliștirmede etkisi (Yayınlanmamış yüksek lisans tezi). Trabzon Üniversitesi, Lisansüstü Eğitim Enstitüsü, Trabzon.

Y28 Uşengül, L. (2019). Lego wedo 2.0 eğitiminin öğrenenlerin fen bilimlerine yönelik akademik başarı ve tutumları ile bilgi işlemsel düşünme becerilerine etkisi (Yayınlanmamış yüksek lisans tezi). Fırat Üniversitesi, Eğitim Bilimleri Enstitüsü, Elazı̆g.

Y29 Şenol, Ş. (2019). İlkokulda kodlama eğitimi: sınıf öğretmenleri örneği (Yayınlanmamış yüksek lisans tezi). Süleyman Demirel Üniversitesi, Eğitim Bilimleri Enstitüsü, Isparta.

Y30 Altun, H. (2017). Teknolojik pedagojik alan bilgisi (tpac) çerçevesi ile oluşturulmuş programlama eğitiminin öğrenme çıktıları üzerine etkileri (Yayınlanmamış yüksek lisans tezi). Necmettin Erbakan Üniversitesi, Eğitim Bilimleri Enstitüsü, Konya.

D1 Taş, N. (2018). Farklılaştırılmış bilgisayar destekli matematik etkinliklerinin üstün yeteneklilerin bilgi işlemsel düşünme öz yeterlikleri ve matematiğe yönelik tutumlarına etkisi (Yayınlanmamış Doktora tezi). Atatürk Üniversitesi, Eğitim Bilimleri Enstitüsü, Erzurum.

D2 Berikan, B. (2018). Bilgi işlemsel düşünme becerisine yönelik tasarlanan "veri setleriyle problem çözme" öğrenme deneyiminin biçimlendirici değerlendirmesi (Yayınlanmamış Doktora tezi). Gazi Üniversitesi, Eğitim Bilimleri Enstitüsü, Ankara.

D3 Kukul, V. (2018). Programlama öğretiminde farklı yapılandırılan süreçlerin öğrencilerin bilgi işlemsel düşünme becerilerine, öz yeterliliklerine ve programlama başarılarına etkisi (Yayınlanmamış Doktora tezi). Gazi Üniversitesi, Eğitim Bilimleri Enstitüsü, Ankara.

D4 Üzümcü, Ö. (2019). Bilgi işlemsel düşünme becerisine yönelik program tasarımının geliştirilmesi ve etkililiğinin değerlendirilmesi (Yayınlanmamış Doktora tezi). Gaziantep Üniversitesi, Eğitim Bilimleri Enstitüsü, Gaziantep.

D5 Atiker, B. (2019). Programlama öğretiminde ortaokul öğrencilerinin bilgi işlemsel düşünme becerilerinin başarıya etkileri (Yayınlanmamış Doktora tezi). İstanbul Üniversitesi, Fen Bilimleri Enstitüsü, İstanbul.

D6 Ceylan, V. K. (2020). Senaryo temelli scratch öğretim programının öğrencilerin bilgi işlemsel düşünme becerilerine, problem çözme ve programlama ünitesi erişilerine etkisi (Yayınlanmamış Doktora tezi). Aydın Adnan Menderes Üniversitesi, Sosyal Bilimler Enstitüsü, Aydın.

D7 Avcu, Y.E. (2019). Özel yetenekli öğrenciler için bilişim teknolojileri ve yazılım alanına yönelik bir öğretim tasarımının geliştirilmesi (Yayınlanmamış Doktora tezi). Balıkesir Üniversitesi, Sosyal Bilimler Enstitüsü, Balıkesir.

D8 Çetin, E. (2016). Okul öncesi çocukların problem çözme sürecinde teknoloji destekli şematik düzenleyicilerin kullanımına yönelik bir durum çalışması (Yayınlanmamış Doktora tezi). Gazi Üniversitesi, eğitim Bilimleri Enstitüsü, Ankara. 
“Türkiye'de Bilgi İşlemsel Düşünme Becerisi ile İlgili Yapılmış Lisansüstü Tezlerin Tematik ve Yöntemsel Eğilimleri” başlıklı çalışmanın yazım sürecinde bilimsel, etik ve alıntı kurallarına uyulmuş; toplanan veriler üzerinde herhangi bir tahrifat yapılmamış, karşılaşılacak tüm etik ihlallerde "Sakarya University Journal of Education Dergisi ve Editörünün" hiçbir sorumluluğunun olmadığı, tüm sorumluluğun yazara ait olduğu ve çalışmanın herhangi başka bir akademik yayın ortamına değerlendirme için gönderilmemiş olduğu bu çalışmanın yazarı tarafından taahhüt edilmiştir. 